\title{
The microRNA-200 family: small molecules with novel roles in cancer development, progression and therapy
}

\author{
Brock Humphries ${ }^{1,2}$, Chengfeng Yang ${ }^{1,2,3}$ \\ ${ }^{1}$ Department of Physiology, Michigan State University, East Lansing, MI 48824, USA \\ ${ }^{2}$ Cellular and Molecular Biology Graduate Program, Michigan State University, East Lansing, MI 48824, USA \\ ${ }^{3}$ Center for Integrative Toxicology, Michigan State University, East Lansing, MI 48824, USA \\ Correspondence to: \\ Chengfeng Yang, e-mail: yangcf@msu.edu \\ Keywords: microRNA, miR-200, cancer initiation, cancer metastasis, cancer therapeutic target \\ Received: November 14, 2014 \\ Accepted: January 06, 2015 \\ Published: January 30, 2015
}

\section{ABSTRACT}

MicroRNAs (miRNAs) are a large family of small non-coding RNAs that negatively regulate protein-coding gene expression post-transcriptionally via base pairing between the $5 \bowtie$ seed region of a miRNA and the $3 \bowtie$ untranslated region (3凶UTR) of a messenger RNA (mRNA). Recent evidence has supported the critical role that miRNAs play in many diseases including cancer. The miR-200 family consisting of 5 members (miR-200a, -200b, -200c, -141, -429) is an emerging miRNA family that has been shown to play crucial roles in cancer initiation and metastasis, and potentially be important for the diagnosis and treatment of cancer. While miR-200s were found to be critically involved in the metastatic colonization to the lungs in mouse mammary xenograft tumor models, a large number of studies demonstrated their strong suppressive effects on cell transformation, cancer cell proliferation, migration, invasion, tumor growth and metastasis. This review aims to discuss research findings about the role of the miR-200 family in cancer initiation, each step of cancer metastatic cascade, cancer diagnosis and treatment. A comprehensive summary of currently validated miR-200 targets is also presented. It is concluded that miR-200 family may serve as novel targets for the therapy of multiple types of cancer.

\section{INTRODUCTION}

The miRNAs

The first microRNA (miRNA) (lin-4) was discovered in 1993 [1, 2], however the term "microRNA" wasn't introduced until 2001 [3-5]. Within the next year it was reported for the first time that miRNAs are likely involved in cancer, by demonstrating that miR-15 and -16 were frequently deleted in chronic lymphocytic leukemia (CLL) [6]. Since this discovery a focus has been put on identifying and determining the role of miRNAs involved in cancer development, progression, diagnosis and treatment. Through this effort, our understanding of how microRNAs function and the role they play in cancer has increased tremendously.

MiRNAs are a large family of small non-coding RNA molecules (over 2500 in humans: miRBase.org) that negatively regulate protein-coding gene expression post-transcriptionally. MiRNAs are initially transcribed mono- or polycistronically in the nucleus by RNA polymerase II into primary transcripts (termed primary miRNA, pri-miRNA) ranging from hundreds to thousands of nucleotides long, which are then polyadenylated and capped $[7,8]$. These pri-miRNA transcripts are subjected to a microprocessing event carried out by a type III RNase Drosha and its binding partner DiGeorge Syndrome Critical Region 8 (DGCR8) to reduce the size of the transcript to $\sim 70$ nucleotides termed precursor- or pre-miRNA $[9,10]$. The pre-miRNA is then exported to the cytosol by exportin-5, where it undergoes another processing event performed by another type III RNase Dicer resulting in a 21-22 nucleotide miRNA duplex [11, 12]. After unwinding, one strand of the duplex is usually degraded, while the other strand, the mature miRNA, is associated with Argonaute and then incorporated into the RNA induced silencing complex (RISC), where miRNAs are then able to regulate the expression of their target genes. 
Although it has been shown that miRNAs can interact with other parts of the messenger RNAs (mRNAs) (for example see [13]), miRNAs typically function by base pairing with the $3 \otimes$ untranslated regions (3区-UTRs) of their target mRNAs through the seed sequences of the miRNAs. The seed sequence of a miRNA is the second to the eighth nucleotide region at the $5 \otimes$ end of the mature miRNA that generates the specificity of each miRNA to its target mRNAs. The base pairing between a miRNA and its target mRNAs can result in mRNA destabilization and degradation, translational inhibition, or mRNA direct cleavage [1417]. Down-regulation of mRNAs through miRNA-caused mRNA destabilization and degradation is common, which is usually mediated by the same imperfect miRNA:mRNA base pairing that leads to translational inhibition [18-20]. Conversely, mRNA down-regulation through miRNAcaused mRNA direct cleavage occurs in rare cases, which usually requires more extensive base pairing $[16$, 17]. While a miRNA's seed sequence is usually the most prominent characteristic that determines the specificity of the miRNA:mRNA interaction, there are examples of miRNAs that have weak seed sequence binding but better overall complementarity which can direct the inhibition of gene expression $[15,21,22]$.

MiRNAs are interesting because each can target multiple genes and can also share seed sequences with other miRNAs, therefore theoretically targeting the same genes as other miRNAs. It is for this reason that miRNAs have been thought to regulate upwards of two-thirds of all protein coding genes in humans [23]. Furthermore, miRNAs have been shown to be involved in almost all aspects of cellular functions. Therefore it is probable that miRNAs play critical roles in cancer development and progression. Indeed there is a growing body of evidence suggesting that miRNAs may act as either oncogenes or tumor suppressors, and are involved in the development, progression, and treatment of cancer (for reviews see $[24,25])$. These miRNAs that act as either oncogenes or tumor suppressors in a cell are often called oncomirs [26].

\section{The miRNA-200 family}

The miRNA-200 (miR-200) family consists of five members, which form two clusters located in two different genomic regions. As shown in Figure 1, the Cluster I miR-200s in humans contains $m i R-200 b,-200 a$, and -429 ( $m i R-200 b / 200 a / 429)$ located in an intergenic region of chromosome 1 , and cluster II miR-200s contains $m i R$ $200 \mathrm{c}$ and -141 (miR-200c/141) located on chromosome $12[27,28]$. Alternatively, the miR-200 family members can also be divided into two functional groups based upon the similarities of their seed sequences (Figure 2). MiR200b, -200c, and -429 (Functional Group I) all share the same seed sequence and miR-200a and -141 (Functional
Group II) both share the same seed sequence, with the two functional groups only differing in the seed sequence by one nucleotide (AA $\underline{U} A C U G$ for miR-200b/200c/429 and AACACUG for miR-200a/141). The miR-200 family is highly conserved among vertebrate species and highly expressed within epithelial cells.

The expression of the miR-200 family can be regulated through interactions with, and modifications of their promoters. Recent studies suggest that modifications to the promoter regions of each of the miR-200 clusters can cause the loss of the expression of the miR-200 family in cancer. The promoter region of the miR$200 c /-141$ cluster has been shown to be hypermethylated $[29,30]$, whereas the $m i R-200 b /-200 a /-429$ cluster has been shown to be silenced primarily through polycomb group-mediated histone modifications [31] in cancer. Alternatively, the promoter regions of the miR-200 family can be bound by the transcription factors zinc finger e-box bind homeobox 1 (ZEB1) and 2 (ZEB2 also known as SIP1), specificity protein 1 (Sp1), and $\mathrm{p} 53$. When bound, ZEB1 and ZEB2 can inhibit the transcription of the entire miR-200 family, while Sp1 and p53 binding has been shown to lead to activation of transcription of the $m i R-200 b / 200 a / 429[32,33]$ and the $m i R-200 c / 141$ $[33,34]$ clusters, respectively. However, Kolesnikoff and colleagues also showed that Sp1-mediated activation of $m i R-200 b / 200 a / 429$ transcription can be disrupted by the expression and interaction of ZEB1/2 with its binding sites within the promoter.

The miR-200 family is among the most widely studied miRNAs in cancer, this review will focus specifically on the role of the miR-200 family in cancer initiation, metastasis, diagnosis and treatment.

\section{The miR-200 family in cell transformation and tumorigenesis}

Tumor initiation is a complex process by which normal cells are transformed into malignant tumor cells, which then produce a tumor. Throughout this process the molecular profile of the cell is changed in such a way as to allow these cells the ability to form a tumor. Recent research has suggested that the miR-200 family plays an important role in inhibiting cell malignant transformation and preventing tumor initiation.

Recent research done in our laboratory has been the first to show an important role of the miR-200 family in inhibiting and preventing cell malignant transformation by a carcinogen exposure [35]. Using immortalized human bronchial epithelial cells (HBECs) that either had normal p53 expression (HBECs) or p53 knocked down (p53 low HBECs), we were able to show that chronic exposure to a low concentration of arsenic caused epithelial to mesenchymal transition (EMT) and malignant transformation in p53 low HBECs, but not in p53 intact HBECs. Only the 


\section{Chromosome 1}

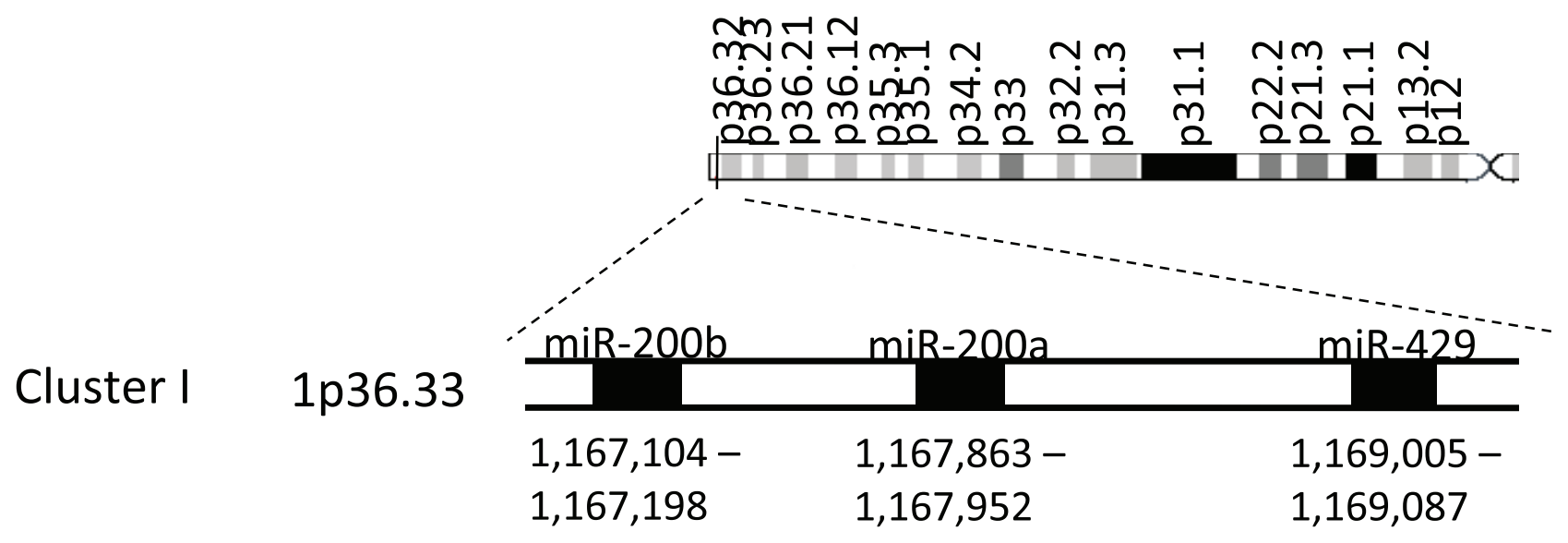

\section{Chromosome 12}

\section{Cluster II 12p13.31}

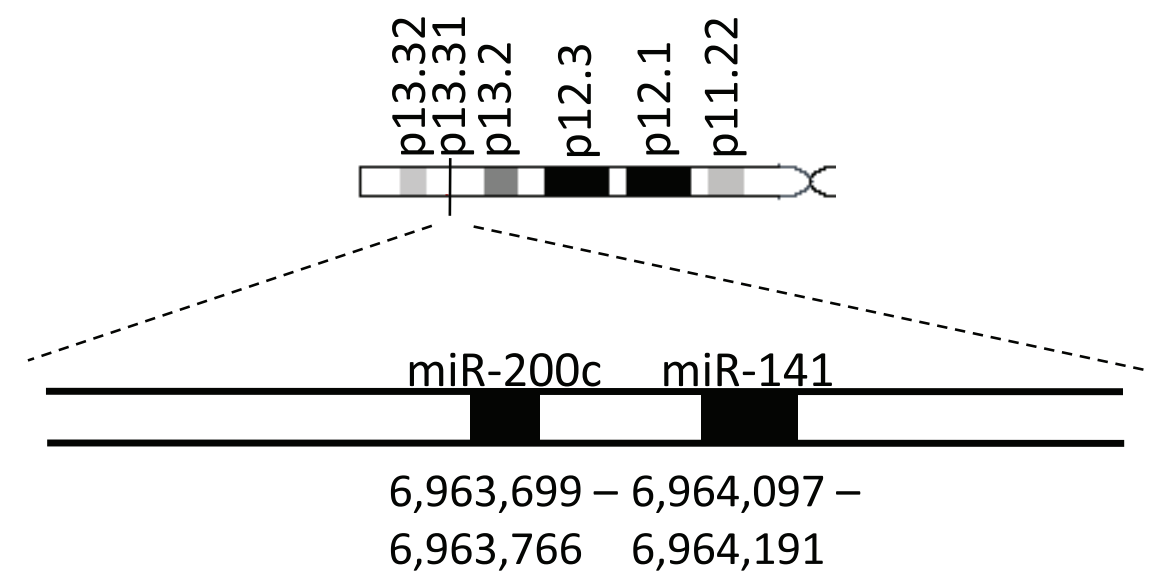

Figure 1: The miR-200 family two clusters are located on two different chromosomes. The miR-200 family consists of two clusters: Cluster I (miR-200b, -200a, and -429 is located on chromosome 1) and Cluster II ( $m i R-200 c$ and -141 is located on chromosome 12).

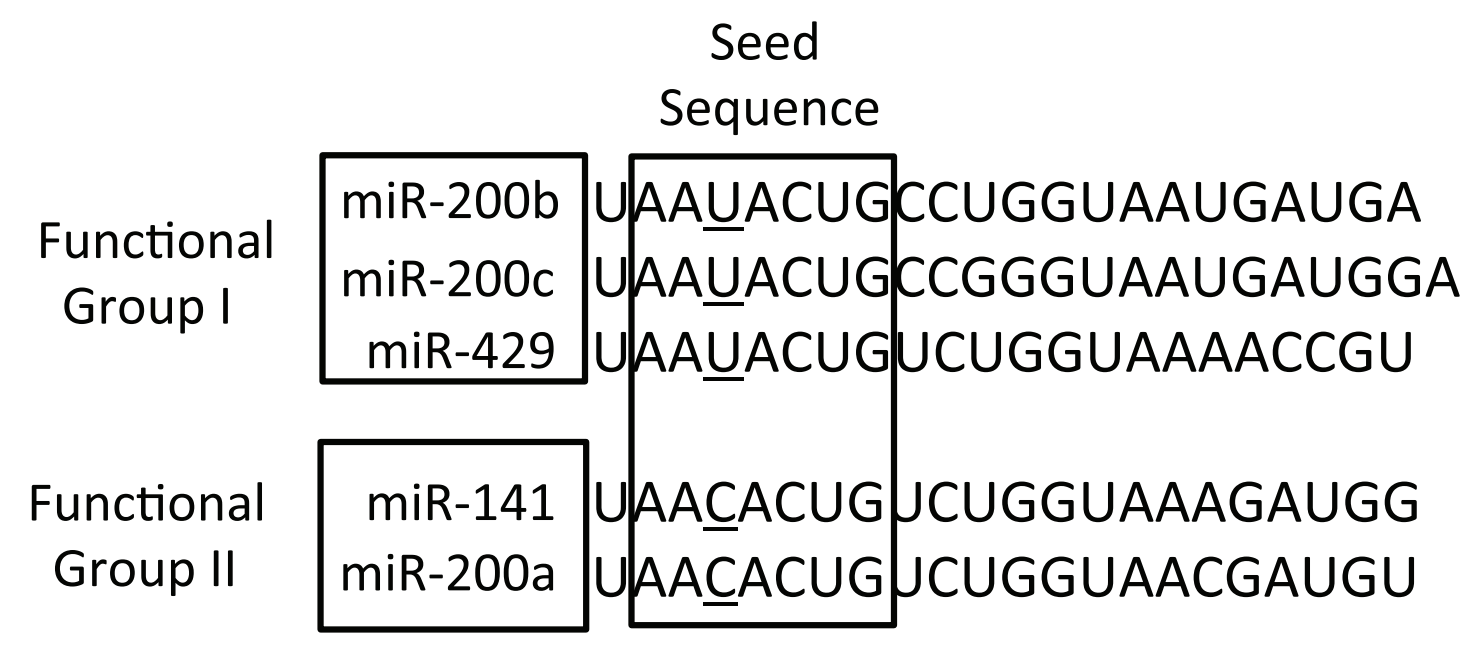

Figure 2: The sequences of the mature miRNA-200 family members. The miR-200 family members can also be separated into two functional groups based upon their seed sequences. Functional Group I is composed of miR-200b, -200c, and -429 and Functional Group II consists of miR-141 and -200a. The seed sequences of these two functional groups only differs by one nucleotide: AAUACUG for group I and AACACUG for group II. 
p53 $3^{\text {low } H B E C s ~ e x p o s e d ~ t o ~ a r s e n i c ~ f o r m e d ~ c o l o n i e s ~ i n ~ s o f t ~}$ agar and formed tumors in a subcuteaneous injection of the cells into the nude mice. A miRNA microarray analysis showed that the expression levels of miR-200 family were drastically reduced in arsenic-transformed cells.

To determine whether down-regulation of the miR200 family plays a role in arsenic-induced cell malignant transformation, we first transiently re-expressed miR$200 \mathrm{~b}$ or $-200 \mathrm{c}$ in arsenic-transformed cells and found that re-expression of miR-200b or $-200 \mathrm{c}$ alone or together restored E-cadherin expression and the epithelial-like cellular morphology, and reduced the formation of colonies in soft agar. Then we generated miR-200b stable expression cells and found that stably re-expressing miR$200 \mathrm{~b}$ in arsenic-transformed cells abolished their ability to form colonies in soft agar, and tumors in nude mice when injected subcutaneously. Then we overexpressed miR-200b in parental $\mathrm{p} 53^{\text {low }} \mathrm{HBEC}$ and found that forced expression of miR-200b prevented cellular transformation by chronic low dose arsenic exposure [35]. Together, these findings suggest that loss of miR-200 expression plays a causal role in arsenic-induced cell malignant transformation and tumorigenesis.

A study investigating the mechanism of tobacco carcinogen-induced cell transformation showed that a 4 week treatment of p53 intact HBECs with genotoxic, but not cytotoxic, doses of $N$-Nitroso- $N$-methylurea (NMU) or Benzo(a)pyrene diolepoxide (BPDE) caused EMT and cell transformation as evidenced by occurrence of mesenchymal-like cellular morphology and increased soft agar colony formation [36]. Further experiments revealed that expression of miR-200b and -200c were significantly reduced after 4 week carcinogen treatment. Transient or stable expression of these miRNAs in tobacco carcinogentransformed HBECs restored the epithelial-like cellular morphology and reduced soft agar colony formation [36].

These two studies described above both looked at epigenetic silencing as a possible mechanism for the carcinogen-induced miR-200 expression loss seen in the HBECs. It was determined that the promoter regions of the miR-200 family were indeed highly methylated upon treatment with the carcinogen, and demethylation induced by DNA methyltransferase inhibitors or demethylation chemicals increased the expression of the miR-200 family. Therefore, arsenic or tobacco carcinogens may induce cell transformation by increasing the methylation of the promoter regions of, and subsequently leading to silencing of, the miR-200 family. Together, these studies suggest that loss of miR-200 expression may play an important role in the early stage of carcinogenesis.

\section{The miR-200 family in cancer metastasis}

Cancer metastasis is the result of a multi-step signaling cascade in which cancer cells move away from the primary tumor site to colonize distant organs and form secondary (or metastatic) tumors [37]. Typically, cells that accomplish metastasis have undergone widespread genetic and epigenetic modifications that benefit the survival, growth, invasion and movement of the cell. Metastasis can be broken down into 6 steps [38]: 1) growth and vascularization of the primary tumor, and nearby tissue invasion, 2) detachment of the cancer cells and migration away from the primary tumor, 3) intravasation into the blood stream and lymph nodes, 4) survival and circularization within the blood stream and lymph nodes, 5) attachment to the blood vessel wall and extravasation, and finally 6) colonization of the distant organs and growth of metastatic tumors. Each step symbolizes an important obstacle that the tumor cell must overcome to result in successful metastasis.

Current research on the miR-200 family has shown that the family can affect each step of the metastatic cascade. Therefore, this section will summarize these works in respect to the order of each metastatic step as described above.

\section{Effect of the miR-200 family on tumor growth, angiogenesis, and nearby tissue invasion}

Once a cell undergoes transformation to a malignant cell, the checkpoints that limit its growth are bypassed resulting in uncontrolled growth. This uncontrolled growth leads to the formation of a primary tumor. Not only has the miR-200 family been shown to inhibit cellular malignant transformation, but studies have also shown that they are capable of suppressing tumor growth. For example, it was found that forced expression of miR-200a in meningioma cells [39], or expression of miR-429 in SW260 colorectal carcinoma cells [40], reduced xenograft tumor growth when injected into the flanks of SCID or nude mice, respectively. However, the reported effects of miR-200b on xenograft tumor growth are less consistent as some studies including ours have shown that expression of miR-200b decreased tumor growth [41, 42] while others have shown that it has little or no effect on tumor growth $[43,44]$. Therefore more work is needed to determine the role of the miR-200 family in this early step of metastasis.

Once a tumor reaches $1-2 \mathrm{~mm}^{3}$ the cells at the center of the tumor are under hypoxic conditions and do not receive enough nutrients to grow [45]. In order to combat this environment a tumor must initiate angiogenesis, which allows new blood vessels to form intricately within the tumor. Recent studies have shown that the miR-200 family can inhibit angiogenesis because the family targets multiple key players in this process.

In this regard, two separate studies have shown that miR-200b directly targets vascular endothelial growth factor A (VEGFA) [46, 47], a ligand that is considered the master determinant for the activation of the angiogenic program. Furthermore, the miR-200 family has also been shown to target the VEGF receptors. For example, in 
A549 lung cancer cells, Choi and colleagues demonstrated that transient miR-200b expression reduced Flt1 (VEGF receptor 1) and KDR (VEGF receptor 2) protein level, and a luciferase reporter assay confirmed the direct interaction between miR-200b and the 3区UTR of these proteins. Similarly, miR-200c has also been shown to directly target KDR [48]. These findings were further confirmed by Roybal and colleagues showing that stable expression of cluster I miR-200s reduced protein and mRNA levels of the receptor tyrosine kinase Flt1 (VEGFR1) in lung adenocarcinoma 344SQ cells [49]. Additionally, miR200a and miR-200b have also been shown to directly target the pro-angiogenic ligands interleukin 8 (IL-8) and chemokine (C-X-C motif) ligand 1 (CXCL1) to regulate angiogenesis in ovarian cancer [50]. Taken together, these data suggest that the miR-200 family plays crucial roles in the metastatic cascade by down-regulating important players involved in angiogenesis.

Research in our lab has also shown an important role of miR-200b in inhibiting tumor angiogenesis. Ours and other studies showed that inoculation of arsenictransformed cells produced invasive and metastatic xenograft tumors in nude mice [51-53], however, the underlying mechanism is not clear. To examine whether arsenic-transformed cells have a pro-angiogenic activity, we tested the effect of conditioned media from these cells on the tube forming ability of human umbilical vein epithelial cells (HUVECs). HUVECs cultured in conditioned media from arsenic-transformed cells formed extensive tubes compared to HUVECs cultured in conditioned media from non-transformed control cells, suggesting a pro-angiogenic capability of arsenictransformed cells [54]. To study the role of miR-200b in this process, we used conditioned media from arsenictransformed cells that stably expressed miR-200b. It was found that HUVECs cultured in conditioned media from arsenic-transformed cells stably expressing miR$200 \mathrm{~b}$ formed significantly less tubes. Furthermore, the immunofluorescence staining of CD31, a marker of blood vessel endothelial cells, on xenograft tissues resulting from the injection of arsenic-transformed cells stably expressing miR-200b showed a drastic reduction compared to CD31 staining on xenograft tumors resulting from the injection of arsenic-transformed vector control cells [54]. Our additional mechanistic studies suggested that this reduction of angiogenesis by miR-200b is likely due to down-regulation of VEGF levels resulting from $\beta$-catenin sequestration at the plasma membrane by increased expression of E-cadherin. Together, these findings provide additional evidence supporting that miR$200 \mathrm{~b}$ is capable of inhibiting tumor angiogenesis.

Tumor nearby tissue invasion involves breakage of the boundaries of tissues where tumors originate from and the entry of cancer cells from the primary tumor into the surrounding stroma. Sossey-Alaoui and colleagues found that WAS protein family member 3 (WAVE3) was critical for the invasive properties of transformed cells [55]. Further analysis revealed that miR-200b directly targets WAVE3 through interaction with its 3区UTR in MDAMB-231 breast, LNCaP prostate, and HT29 colorectal cancer cells. To study the effects of WAVE3 on cell invasion, a Matrigel-invasion assay showed that cells treated with WAVE3 siRNA or that overexpression of miR-200b reduced the invasive capability, while using an anti-miR-200b oligonucleotide increased the number of invading cells. Expressing a WAVE3 mRNA that is resistant to miR-200b targeting also reversed the inhibitory effects of miR-200b on cell invasion, further suggesting a critical role for miR-200b in the inhibition of WAVE3dependent cellular invasion.

Another study looked at the effects of miR-200 on targets that regulate the reorganization of the actin cytoskeleton to promote invasiveness [56]. Transient transfection of a miR-200c mimic in MDA-MB-231 breast cancer cells showed a strong inhibitory effect on the invasive capabilities of these cells in Matrigel and when using a real-time cell analyzer. Furthermore, the increase in the level of miR-200c was accompanied by a decrease in stress fiber formation that was not accompanied by a change in RhoA activity, suggesting that miR-200c likely acted downstream of RhoA. Transient transfection of miR-200c reduced both formin homology domaincontaining protein 1 (FHOD1) and $\mathrm{Mg}^{2+} / \mathrm{Mn}^{2+}$-dependent protein phosphatase 1F (PPM1F) levels, and inhibition of the miR-200b/c/429 cluster in MCF7 breast cancer cells increased FHOD1 and PPM1F levels. A luciferase reporter assay confirmed that miR-200c directly targets the 3凶UTR of these mRNAs in MDA-MB-231, MCF-7, and HEK293FT cells. Silencing of FHOD1 or PPM1F resulted in decreased invasion in MDA-MB-231 cells using the same assays as before, showing the importance of these targets in invasion.

$\mathrm{Li}$ and colleagues found that miR-200c expression was significantly lower in A549, H1299, and SPC-A-1sci non-small cell lung cancer (NSCLC) cells among other NSCLC cells [57]. Transwell invasion assays showed that these cell lines that expressed lower levels of miR$200 \mathrm{c}$ had a higher invasive capability than other NSCLC cells. Furthermore when these highly invasive cells were transiently transfected with miR-200c mimics, their invasive abilities were significantly decreased compared to cells transfected with control oligos, which suggests a suppressive role for miR-200c on NSCLC cell invasion. Bioinformatic analysis suggested ubiquitin specific peptidase 25 (USP25) as a potential target for miR-200c and a luciferase reporter assay confirmed the direct binding of miR-200c to its $3 \otimes U T R$. To further show the importance of this protein in cellular invasion, knockdown of USP25 significantly reduced cell invasion and its overexpression increased cell invasion as assayed by transwell invasion assays. 


\section{Effect of the miR-200 family on epithelial- to-mesenchymal transition and tumor cell migration}

One of the most critical properties that a tumor cell must obtain in order to metastasize is the ability to move away from the primary tumor. One of the most widely studied cellular programs that tumors cells activate to gain this motility is known as the epithelialto-mesenchymal transition (EMT). EMT is a process by which a normally polar, epithelial cell undergoes a change to a mesenchymal-like cell. By undergoing EMT, a cell is able to take on the characteristics of a mesenchymal cell and become more motile and invasive. Accompanying this morphological change is a shift in expressed proteins, and an increase in the production of transcription factors and extracellular matrix degrading enzymes within the cell. EMT occurs naturally during embryogenesis; however it is now thought to be a major contributor to the metastasis of epithelial-originated cancers.

Two of the major hallmarks of EMT include a loss of the epithelial markers such as E-cadherin, a cellcell adhesion protein, and the increase in the expression of mesenchymal markers such as ZEB1, ZEB2 and other EMT-inducing transcription factors. These two hallmarks are mutually exclusive from the other within an epithelial cell. ZEB1 and ZEB2 act as E-cadherin repressors by directly binding to the E-boxes within the E-cadherin promoter [58-60], thus ZEB1 and ZEB2 are directly involved in the control of EMT by suppressing the expression of E-cadherin, and their expression promotes cell migration and invasion. Recent studies suggest that the miR-200 family is pivotal in regulating EMT by targeting ZEB1 and ZEB2 via direct interactions with their 3区UTRs [61-63]. Through down-regulating ZEB1 and ZEB2 expression, the miR-200 family can effectively up-regulate cellular E-cadherin level and maintain a cell in a more epithelial-like state. However, ZEB1 and ZEB2 can also bind to the E-box sites close to the transcription start site of each of the miR-200 clusters inhibiting their transcription, resulting in a negative feedback loop $[64,65]$. Thus, ZEB1 and ZEB2 can keep a cell in a mesenchymal phenotype by repressing the transcription of both E-cadherin and the miR-200 family. Therefore, the interplay between the miR-200 family and ZEB1/ZEB2 plays an important role in driving the cell in to and out of EMT.

Cell migration is a critical step in the metastatic cascade where tumor cells move away from the primary tumor to enter the blood stream. Early studies on the miR-200 family have shown that the miR-200 family can suppress cell migration. Gregory et al. first reported the inhibitory effect of miR-200 on cell migration using a transwell migration assay [61]. Using specific miR-200 inhibitors, this group found that the miR-200 inhibitors increased cell migration of Madin-Darby canine kidney epithelial cells, suggesting that the miR-200 family inhibits cell migration. Similarly, Park et al. found that expressing $\mathrm{miR}-200 \mathrm{a} / \mathrm{c}$ in the highly metastatic MDAMB-231 breast cancer cells significantly decreased their motility in a transwell migration assay [62]. Both of these studies also showed that cells that have undergone EMT have an increased motility as well as an increase in the expression of the mesenchymal markers ZEB1, ZEB2 and vimentin. Furthermore, these and others have shown that the miR-200 family is a strong inhibitor of EMT, and that EMT resulting from the loss of the miR-200 family depends on ZEB1 and/or ZEB2 up-regulation. Therefore, it was concluded that the miR-200 family elicits this inhibitory effect on cell migration by targeting both ZEB1/2.

However, ours and other recent studies also suggest that the miR-200 family can inhibit cell migration independent of its effect on ZEB1/ZEB2. Li and colleagues found that mammary fat pad injection of the metastatic MDA-MB-231 LM2 breast cancer cells resulted in metastasis to the lung and bone, and this was greatly reduced by the stable expression of miR-200b or miR-200c [43]. This suppressive effect on metastasis was not seen when miR-141 was stably expressed in these cells suggesting that the functional group I miR-200s (miR-200b/-200c/-429) is able to repress metastasis in these cells. To determine whether miR-200 suppresses metastasis by targeting ZEB1, the ZEB1 expressing cDNA lacking the 3凶UTR was engineered into the MDAMB-231 LM2 cells that stably expressed miR-200b. It was found that miR-200b was still able to inhibit metastasis when ZEB1 was forcibly expressed, which implies that miR-200b can inhibit metastasis in a ZEB1-independent manner. Through invasion assays and luciferase reporter assays, it was determined that miR-200b regulates cell migration and metastasis by targeting moesin, and restoration of moesin prevents miR-200b from suppressing cell migration and metastasis.

Our recent studies have also implicated the miR200 family in the ZEB1-independent regulation of cell migration and metastasis. In the highly migratory arsenic-transformed cells and basal mesenchymallike triple negative breast cancer cells, we found that $\mathrm{PKC} \alpha$ expression levels are significantly higher, and re-expression of miR-200b reduced PKC $\alpha$ levels and inhibited cell migration as well as mammary tumor metastasis [42, 66]. Subsequent luciferase reporter assays revealed that miR-200b directly targets the 3 \UTR of PKC $\alpha$. Moreover, siRNA knockdown of PKC $\alpha$ significantly reduced cell migration. In contrast, enforced expression of PKC $\alpha$ reversed the inhibitory effect of miR-200b on cell migration and tumor metastasis with no significant effect on ZEB1 expression. These findings suggest that miR-200b suppresses cell migration and metastasis by targeting $\mathrm{PKC} \alpha$, which is independent of its effect on ZEB1. 
By applying the Ago-HITS-CLIP technology for transcriptome-wide identification of direct miRNA targets in living cells, Bracken et al recently identified a good number of miR-200a and miR-200b targets [67]. Further functional validation of the identified miR-200 targets revealed that they constitute subnetworks that play crucial roles in enabling cancer cells to migrate and invade. The identified miR-200 targets are critically involved in Rho-ROCK signaling, invadopodia formation, matrix metalloproteinase activity, and focal adhesions. This work showed for the first time a global regulatory network directly regulated by miR200 family, which provided a novel mechanistic insight for miR-200 family maintaining the key features of the epithelial phenotype and preventing cell migration.

\section{Effect of the miR-200 family on tumor cell intravasation}

Intravasation is a complex step that involves cancer cells entering the blood vessels or lymphatic system. It can be aided by gene changes that promote the ability of cancer cells to cross the basement and endothelial membranes that form the walls of the vessels. Notch signaling [68] and tumor-associated macrophages (TAMs) [69] are two example mechanisms that have been shown to positively modulate intravasation of cancer cells. In addition to these mechanisms, new blood vessels that have been formed by the primary tumor are leaky and therefore can also facilitate intravasation $[70,71]$. It has been shown that stably expressing both miR-200 cluster members reduced the ability of cancer cells to enter the blood stream, and that E-cadherin overexpression can also decrease the number of cells in the blood stream [72]. However, there has been little research done with respect to the mechanism by which miR-200 family reduces cancer cell intravasation. This is probably partly due to the difficulty in measuring intravasated cells in the blood stream, and that the miR-200 family has a strong suppressive effect on the earlier steps of the metastatic cascade. More research is needed to fully understand the intravasation process, and development of a system in which we can directly observe and measure intravasation is critical in doing that.

\section{Effect of the miR-200 family on tumor cell survival in circulation}

After tumor cells have successfully intravasated into the blood stream, they can circulate throughout the body. These tumor cells that have entered the blood stream are known as circulating tumor cells (CTCs). Since the blood stream is such a harsh environment, these CTCs need to adopt a molecular profile that promotes survival in the blood stream. Therefore CTCs often reprogram certain cellular programs such as apoptosis and anoikis to survive. MiR-200 family members have been shown to regulate apoptosis and anoikis, and therefore may have an effect on tumor cell survival in circulation.

In the case of apoptosis, Uhlmann et al. found that in MDA-MB-231 breast cancer cells, overexpression of the miR-200b/c/429 cluster significantly reduced cell viability and increased apoptosis [73]. It was further confirmed that PLC $\gamma 1$ was a direct target of the miR-200b/c/429 cluster, and PLC $\gamma 1$ knockdown resulted in reduced cell viability and increased caspase activity.

Schickel et al. found that stably expressing miR200c in CAKI-1 kidney and HeyA8 ovarian or transiently expressing it in ACHN kidney cancer cells, caused these cells to be much more sensitive to CD95 (a death receptor)-mediated apoptosis when treated with a CD95 agonist [74]. It was confirmed that miR-200c directly targets FAP-1, a known inhibitor of CD95-mediated apoptosis in these cells, and that the likely mechanism for the sensitivity seen was due to an increase of CD95 surface expression because of FAP-1 suppression. In another study, miR-200c was shown to target Noxa, a member of the Bcl-2 family, in MCF7 breast cancer cells [75]. Through functional studies in these cells it was determined that miR-200c potentiates apoptosis to the clinically used proteasome inhibitor bortezomib by reducing Noxa levels. In addition, in meningiomas it was found that miR-200a directly targeted $\beta$-catenin to increase apoptotic cell death [76]. Therefore, downregulation of miR-200 family levels in tumor cells can help the cell survive within the bloodstream by reducing apoptosis.

Anoikis is a kind of apoptosis that is induced by inappropriate or inadequate cell-ECM attachment. Alteration of this complex signaling process can allow tumor cells to survive in the circulatory system that is normally unsuitable for these cells.

Howe et al. demonstrated that miR-200c levels were significantly reduced in BT549 and MDA-MB-231 triple negative breast cancer cells [77]. Further work showed that stably expressing miR-200c induces anoikis in these cells by directly targeting $\operatorname{TrkB}$, a neurotrophic tyrosine receptor kinase. Zhang and colleagues also studied the role of miR-200 in anoikis in breast cancer [78]. Transfection of miR-200b in MDA-MB-231, BT549, and Hs578T TNBC cells increased the number of apoptotic cells in suspension-culture. Pin1, peptidylprolyl cis/trans isomerase, NIMA-interacting 1, was confirmed as a direct target of miR-200b, and simultaneously expressing miR-200b and an untargetable Pin 1 resulted in a decreased number of cells undergoing anoikis in culture. However, in contrast to these studies, Yu et al. found that expression of miR-200a made breast cancer cells more resistant to anoikis [79]. YAP1, yes-associated protein 1, was confirmed to be a direct target of miR-200a and by targeting this protein miR-200a allows cells to avoid anoikis. Given the contradictory results observed, the role of individual members of the miR-200 family in anoikis still needs to be further studied. 
By regulating above cellular processes, cancer cells are able to survive in the harsh circulation system. In addition, immune system differentiation, activation, development, or response could also play critical roles in the survival of intravasated tumor cells. However, little research has been done specifically looking at the effect of the miRNA-200s on immune system regulation. Therefore, more research is needed in order to further elucidate the role that these miRNAs play in this critical step of metastasis.

\section{Effect of the miR-200 family on tumor cell extravasation and metastatic colonization}

The final steps of metastasis involve surviving CTCs coming to arrest in the blood vessels, extravasating from the blood vessels, and colonizing a distant organ. In order for extravasation to occur, CTCs must first come in contact the endothelium either by becoming lodged in smaller vessels or by specifically adhering to the endothelium. Once a circulating tumor cell extravasates from the blood vessels (likely facilitated by ZEB1 and $\mathrm{N}$-cadherin expression [80]), these cells have a tendency to undergo mesenchymal-to-epithelial transition (MET) which is most likely due to the absence of the signals they received from the primary tumor to undergo EMT. MET facilitates the settling of a cancer cell at a distant organ by allowing these cancer cells to recover their epithelial properties. Once a cell settles in the distant organ, it begins to proliferate and colonize the organ. In striking contrast to the strong inhibitory effect of miR-200 family has on the early metastatic steps, studies have shown that miR-200 may promote metastatic colonization [72, 81].

To study the role of miR-200 in the last step of the metastatic cascade, Korpal and colleagues profiled the levels of the miR-200 family in primary and metastatic samples and found that the miR-200 family was higher in metastatic secondary tumors [72]. Moreover, profiling a group of mouse breast cancer cell lines (67NR, 168FARN, 4TO7, and 4T1) with different metastatic capabilities (67NR cells are unable to intravasate; 168FARN cells cannot extravasate efficiently; 4TO7 cells do not colonize distant organs well; and 4T1 cells are capable of completing all steps of metastasis) revealed that the most metastatic cells (4T1) had the highest level of miR-200 family expression. Similarly, Dykxhoorn et al. reported that the 4TO7 cells, lacking the capability of colonizing distant organs, had almost undetectable expression levels of the miR-200b/c/429 cluster compared to the strongly metastatic 4T1 cells [81], suggesting a potential role for the miR-200b/c/429 cluster in colonization. To study the role of the miR-200s in metastatic colonization, Korpal et al. stably expressed cluster I (miR-200b/a/429: which will be referred to as C1), cluster II (miR-200c/141: C2) or clusters I and II $(\mathrm{C} 1+\mathrm{C} 2)$ in the weakly metastatic $4 \mathrm{TO} 7$ cells. Importantly, it was found when C2 was stably expressed the other cluster $(\mathrm{C} 1)$ also showed a significant increase in expression levels; however, $\mathrm{C} 1$ overexpression did not increase the expression levels of C2 miR-200 members. When 4T1 cells, the parental 4TO7 cells and modified 4TO7 cells were injected into the mammary fat pad of mice, it was found that all mice injected with 4T1 cells developed lung and liver metastases, while no mice injected with parental 4TO7 cells had any detectable metastases [81]. In contrast, injection of the modified C2 or $\mathrm{C} 1+\mathrm{C} 24 \mathrm{TO} 7$ cells (cell lines that both express high levels of all five miR-200 members) formed more lung metastases than the parental or $\mathrm{C} 1$ alone overexpressing 4TO7 cells [72]. Furthermore, Dykxhoorn et al. also found that about $80 \%$ of mice injected with $\mathrm{C} 24 \mathrm{TO} 7$ cells developed lung metastases, indicating that the 4TO7 cells that stably express miR-141/200c act similarly to the metastatic 4T1 cells [81]. In addition, Korpal and colleagues also determined that this increase in metastasis by the stable expression of the miR-200s was not due to the increased E-cadherin expression because E-cadherin overexpression alone in these cells caused no increase in lung metastases that was seen in the $\mathrm{C} 2$ and $\mathrm{C} 1+\mathrm{C} 2$ cells [72]. These data suggests that the miR-200 family targets pathways involved in inhibiting metastatic colonization.

To further determine the underlying mechanism behind miR-200 promotion of metastatic colonization, Korpal and colleagues used a tail vein injection model with the modified $4 \mathrm{TO} 7$ cells described above. Results from this experiment showed more lung metastases for all cell lines with $\mathrm{C} 2$ and $\mathrm{C} 1+\mathrm{C} 2$ cells having the greatest effect. Knockdown of E-cadherin in $\mathrm{C} 1+\mathrm{C} 2$ cells did not affect their metastatic efficiency significantly [72]. This again suggested that other targets of the miR-200 family are more important in colonization efficacy of a cancer cell. Through microarray and mass spectrometry analysis nine potential miR-200 targets were identified. Of these nine targets, three were confirmed as direct targets of miR200: cofilin 2 (Cfl2), low-density lipoprotein receptorrelated protein 1 (Lrp1) and Sec23a, a key component of COPII vesicles. Functional analysis in vitro and in vivo revealed that miR-200 increased metastatic colonization by targeting Sec23a. Further analysis also revealed that Tinagl14 and Igfbp4, two secreted metastasis suppressors, are directly regulated by $\operatorname{Sec} 23 \mathrm{a}$ [72].

Interestingly, a recent study showed that the metastatic 4T1 cells, but not the poorly metastatic 4TO7 cells, can secrete miR-200s into extracellular vesicles (EVs) [82]. Moreover, it was also found that the poorly metastatic 4TO7 cells can take up miR-200 from 4T1 EVs and become metastatic in a miR-200-dependent manner [82]. This study provided novel evidence showing that metastatic capability can be transferred from metastatic to non-metastatic cancer cells through extracellular vesicles. In addition, this finding also suggests that circulating miRNAs are not only just cancer biomarkers; they are also functional being capable of promoting metastasis in vivo. 
These studies suggest that even though the miR-200 reduces the number of cancer cells in the bloodstream, probably by strongly inhibiting the early metastatic steps, those cancer cells that have high expression levels of miR-200s and do manage to get through the extravasation step are more capable of colonizing a distant organ. Additionally since these studies have shown that it is the overexpression of the miR-200c/141 cluster that causes the increase in metastatic colonization, it is possible that the miR-200c/141 cluster may act as a suppressor for early steps of metastasis, but facilitates post-extravasation events while the miR-200b/a/429 cluster suppresses metastasis at all steps. However, more research is needed to discern the function of each cluster as a whole and to elucidate the effect of each individual member of the miR200 family on the metastatic cascade.

\section{The miR-200 family as potential diagnostic and prognostic tools}

The search for biomarkers that can serve as an early detection method or as a predictive tool for prognosis is needed to increase the earlier diagnosis and thus the long term survival of cancer patients. The studies of miRNAs as potential diagnostic and prognostic tools mainly stem from reports showing that there are stable, cell-free miRNAs in the blood (termed circulating miRNAs) [83-86], and that circulating miRNAs have specific expression profiles for different cancers, although their origins are currently unclear. Further studies are needed to elucidate whether they come from tumor cell death, are secreted from tumor cells, or originate from blood cells associated with the tumor as well as elucidate their expression patterns in individual cancer types. It is because of this unknown that most studies only show a correlation between a certain cancer and miRNAs.

Studies showed potential in the use of members of the miR-200 family for cancer diagnosis. A genome-wide study by Madhavan et al. found that circulating miRNAs can act as diagnostic markers for circulating tumor cells (CTCs) in metastatic breast cancer (MBC) [87]. Their analysis of CTC-positive versus CTC-negative MBC patients revealed distinct miRNA signatures for each group, and consequently 17 of these miRNAs were further studied. Of these 17 miRNAs, four of them were from the miR-200 family (miR-200b, -200a, -200c, and -141), and this group concluded that miR-200b was the best miRNA for determining CTC-positive MBC patients. Similarly, a study by Cheng et al. found that plasma miR-141 levels are increased in colorectal cancer, highly associated with stage IV colorectal cancer, and able to increase the detection of Stage IV colon cancer when combined with the commonly used colorectal cancer detection marker carcinoembryonic antigen (CEA) [88]. In contrast, Park et al. reported that miR-200a was expressed at lower levels in the saliva of 38 patients with oral squamous cell carcinoma (OSCC) compared to 38 healthy controls [89]. These studies suggest that body fluid miR-200 family levels may have different diagnostic values for different types of cancers.

The use of the miR-200s as a prognostic marker also looks promising. Comparing the expression levels of the miR-200 family members in gastric cancer cell lines, Valladares-Ayerbes and colleagues found that miR200 c levels were much significantly higher in cancer cells compared to normal cells [90]. Further analysis using patient samples showed an inverse correlation between miR-200c blood levels and prognosis, which suggests miR-200c as a potential prognostic biomarker for gastric cancer. $\mathrm{Xu}$ and colleagues were able to show that miR200 family expression was significantly correlated with the status (benign, non-recurrent or recurrent primary, or metastatic) of a melanoma tumor, therefore expanding the potential role of the miR-200 family as a prognostic marker in this disease [91]. In addition, Cheng et al. reported that circulating miR-141 levels were negatively associated with overall survival for the colon cancer patients [88]. Furthermore, a high level of circulating miR141 was found to be associated with high-risk (Gleason score $\geq 8$ ) tumors [92], while a lower level of cluster I of the miR-200 family was correlated with relapse [93] in prostate cancer. High levels of miR-141 were also correlated strongly with decreased overall survival in the luminal subtypes of breast cancer [50]. In contrast, it was found that low expression of cluster I miR-200s (miR-200b, -200a and -429) correlated with poorer overall survival in ovarian and endometrial cancer [94, 95]. Together, these findings suggest that miR-200 levels may have the potential to serve as indicators of cancer prognosis.

It is interesting to note that the majority of data reviewed in previous sections from experimental model systems showing that miR-200s suppress tumor development and progression. However, the clinical diagnostic and prognostic data summarized above are much less consistent about the role of the miR-200s as a suppressor of tumor growth and metastasis. This inconsistence could be due to: (i) the levels of circulating miR-200s, not the levels of miR-200s in cancer tissues in most cases, were used for potential cancer diagnosis and prognosis prediction. However, the origin of circulating miRNA is currently unknown; (ii) it is likely that the role of miR-200s in cancer development and progression may be cancer type-dependent or even cancer subtypedependent. Indeed, Pecot et al. recently reported that higher miR-200 levels in ovarian, lung, renal and basallike breast adenocarcinomas are associated with improved clinical outcome. However, higher levels of miR-141 are significantly associated with worse clinical outcome of luminal subtypes breast cancer [50], suggesting that miR200 may exhibit differential functions among different breast cancer subtypes. 


\section{The potential role of miR-200 family in cancer therapy}

The idea of miRNAs contributing to chemoresistance has been widely studied [96, 97]. The ability of a cell to avoid apoptosis [98] and to undergo EMT [99] have been shown to contribute to the chemoresistance of tumor cells. With the development of microarrays researchers have been able to determine the expression levels and patterns of miRNAs in chemoresistant cells, and this has allowed researchers to determine potential miRNAs involved in the process of apoptosis and chemoresistance. The role of the miR-200 family in apoptosis has already been discussed above in the survival in circulation section; therefore this section will focus primarily on the effect of miR-200s on chemoresistance.

Chemotherapeutic resistance of cancer cells is thought to be one of the primary causes of recurrence in cancer. Although inadequate delivery of the drug to the tumor can contribute to chemoresistance, cellular reprogramming also plays a major role in establishing this resistance. By turning off genes involved in chemosensitivity and turning on genes involved in chemoresistance, tumor cells can effectively evade the drug. Studies have shown that the miR-200 family plays a role in reducing chemoresistance by targeting these genes known to play a direct role in developing this resistance. Liu et al. found that the expression of miR$200 \mathrm{c}$ is decreased in melanoma tissues and cells, with a further decrease in metastatic primary melanoma tumors [100]. In depth analysis revealed that miR-200c reduces the expression of ATP-binding cassette $(\mathrm{ABC})$ transporters ABCG2, ABCG5 and MDR1 in WM115A melanoma cells. This is important because of their known involvement in the multidrug resistance seen in cancer [101]. These findings suggest that downregulation of miR-200c may contribute to the development of chemoresistance in melanoma.

By generating a doxorubicin-resistant breast cancer cell line (BT474), Kopp et al. also showed that loss of miR-200c is important in developing chemoresistance [102]. It was found that miR-200c was significantly downregulated in doxorubicin-resistant cells. When treated with a miR-200c inhibitor, these doxorubicin-resistant BT474 cells became even more resistant to doxorubicin treatment compared to control cells. In contrast, overexpressing miR-200c resensitized these doxorubicinresistant breast cancer cells to doxorubicin treatment. Mechanistic studies from this group determined that miR-200c reduces drug resistance in these cells through targeting Neurotrophic Tyrosine Kinase, Receptor, Type 2 (TrkB) and BMI1 Polycomb Ring Finger Oncogene (BMI1) [102]. In addition, another study revealed that loss of miR-200c expression is associated with poorly differentiated endometrial carcinoma; and restoration of miR-200c in a papillary uterine cancer line significantly increased its chemosensitivity to the microtubule-targeting chemotherapeutics paclitaxel, vincristine, and epothilone $\mathrm{B}$ [103].

Using a miRNA microarray, Kovalchuk and colleagues found that the levels of miR-200a and miR200c were significantly lower in MCF-7 breast cancer cells that were resistant to doxorubicin compared to the parental cells, suggesting that decreased expression of these miRNAs may contribute to doxorubicin resistance in breast cancer [104]. Using the same techniques as Kovalchuk et al., Pogribny and colleagues found that in MCF-7 cells miR-200b and -200 c expression were inversely correlated with resistance to cisplatin [105]. However, in contrast to the findings from above studies, Hamano et al. found that miR-200c overexpression induces cisplatin resistance in esophageal cancer cells (TE8-R) [106], suggesting that the relationship between the miR-200c expression levels and chemoresistance may be cellular context and drug dependent.

A miRNA microarray done by Meng et al. in cholangiocyte cell lines showed that miR-200b and -141 are dysregulated in malignant cholangiocytes [107]. By culturing cholangiocarcinoma cells (Mz-ChA-1) with gemcitabine in the presence or absence of miR-141 or miR-200b inhibitors, they were able to determine that the inhibition of miR-200b decreased gemcitabine-induced apoptosis. Separately, Rui and colleagues also found that decreased miR-200b levels are associated with resistance to docetaxel in a lung adenocarcinoma cell line (SPC-A1 and SPC-A1/docetaxel) [108]. These findings suggest that decreased expression of miR-200b may play a critical role in chemoresistance.

A recent paper by Manavalan et al. has also shown a link between the miR-200 family and targeted therapy resistance in breast cancer cells [109]. The expression levels of the miR-200 family members was determined by qPCR in MCF-7 cells that were either sensitive or resistant (LY2) to endocrine treatment, and showed that the expression of miR-200b, -200a, and -200c was significantly decreased in the endocrine-resistant cell lines. To determine if these miRNAs affected sensitivity to endocrine treatment, the LY2 cells were transiently transfected with their precursor miRNA and cell viability was determined in the presence and absence of the antiestrogens 4-OHT (the active metabolite of tamoxifen) or fulvestrant [109]. Results from this experiment showed that expression of miR-200b and miR-200c enhance the sensitivity of LY2 breast cancer cells to growth inhibition by both 4-OHT and fulvestrant. Therefore, the miR200 family also plays a role in sensitivity to the specific targeted therapies available for breast cancer.

Though much of the research on the miR-200 family in cancer drug resistance has focused mostly on miR-200b and $-200 \mathrm{c}$, it is possible that the other members of the miR-200 family may also play similar roles in the process due to their similar seed sequences. 


\section{CONCLUSIONS AND PERSPECTIVES}

Studies on the miR-200 family have enhanced our knowledge of the crucial roles that they may play in cancer development and progression through targeting a variety of important proteins. A comprehensive list of currently validated miR-200 family targets is presented in Table 1. While miR-200s were found to be critically involved in the metastatic colonization to the lungs, current findings in general support the conclusion that the miR-200 family may mainly function as tumor suppressors and metastatic inhibitors as summarized in Figure 3.
Although current studies on the miR-200 family have shown promising results, more work is needed to further understand the role this family plays in cancer. Future work on the miR-200 family can help with better understanding the mechanism by which miR-200s affect cancer initiation, metastasis, and relapse. Since much work has focused on the effect of whole clusters/ groups on metastasis, more work is also needed to be done on individual members of the miR-200 family to elucidate their role in each step of the metastatic cascade. Developing new and robust models for the study of intravasation and extravasation steps of metastasis are

Table 1: A summary of the validated direct targets of the miR-200 family

\begin{tabular}{lll}
\hline $\begin{array}{l}\text { Direct targets of the } \\
\text { miR-200 family }\end{array}$ & Cell types & Targeted by which Functions of the targets \\
& & miR-200 family \\
& member(s)
\end{tabular}

\begin{tabular}{|c|c|c|c|c|}
\hline $\begin{array}{l}\text { C-Abl Oncogene 2, Non-Receptor } \\
\text { Tyrosine Kinase } \\
\text { (ABL2) }\end{array}$ & Breast & miR-200b & $\begin{array}{l}\text { Binds F-actin and Microtubules; } \\
\text { Plays a Role in Cytoskeletal } \\
\text { Rearrangements }\end{array}$ & {$[67]$} \\
\hline $\begin{array}{l}\text { Adaptor-Related Protein } \\
\text { Complex 1, Sigma } 2 \text { Subunit } \\
\text { (AP1S2) }\end{array}$ & Breast & $\mathrm{miR}-200 \mathrm{a} / \mathrm{b}$ & $\begin{array}{l}\text { Small Subunit of Clathrin- } \\
\text { associated Adaptor Protein } \\
\text { Complex 1; Plays a Role in } \\
\text { Protein Sorting in Golgi }\end{array}$ & {$[67]$} \\
\hline $\begin{array}{l}\text { Anillin, Actin Binding Protein } \\
\text { (ANLN) }\end{array}$ & Breast & $\mathrm{miR}-200 \mathrm{a} / \mathrm{b}$ & Required for Cytokinesis & {$[67]$} \\
\hline $\begin{array}{l}\text { B-Cell CLL/Lymphoma } 2 \\
\text { (BCL2) }\end{array}$ & Stomach, Lung & $\mathrm{miR}-200 \mathrm{~b} / \mathrm{c} / 429$ & $\begin{array}{l}\text { Anti-Apoptotic Protein; } \\
\text { Regulates Cell Death by } \\
\text { Controlling Mitochondrial } \\
\text { Membrane Permeability }\end{array}$ & {$[110]$} \\
\hline $\begin{array}{l}\text { BMI1 Polycomb Ring Finger } \\
\text { Oncogene } \\
\text { (BMI1) }\end{array}$ & Breast, Skin & $\mathrm{miR}-200 \mathrm{~b} / \mathrm{c}$ & $\begin{array}{l}\text { Regulator of Stem Cell Self- } \\
\text { Renewal }\end{array}$ & $\begin{array}{l}{[44,111} \\
112,113]\end{array}$ \\
\hline $\begin{array}{l}\text { Calponin 3, Acidic } \\
\text { (CNN3) }\end{array}$ & Breast & $\mathrm{miR}-200 \mathrm{a} / \mathrm{b}$ & $\begin{array}{l}\text { Implicated in Regulation and } \\
\text { Modulation of Smooth Muscle } \\
\text { Contraction }\end{array}$ & {$[67]$} \\
\hline $\begin{array}{l}\text { Catenin (Cadherin-Associated } \\
\text { Protein), Beta } 1,88 \mathrm{kDa} \\
\text { (CTNNB1) }\end{array}$ & $\begin{array}{l}\text { Brain, Liver, } \\
\text { Nasopharynx }\end{array}$ & miR-200a & $\begin{array}{l}\text { Involved in the Canonical Wnt } \\
\text { Signaling Pathway; Translocates } \\
\text { to Nucleus and Interacts with } \\
\text { TCF/LEF Family Members to } \\
\text { Transcribe Target Genes }\end{array}$ & $\begin{array}{l}{[76,114,} \\
115]\end{array}$ \\
\hline $\begin{array}{l}\text { Cell Division Cycle 25B } \\
(\mathrm{CDC} 25 \mathrm{~B})\end{array}$ & Breast & miR-141 & Required for Entry into Mitosis & [116] \\
\hline $\begin{array}{l}\text { Chemokine (C-X-C Motif) } \\
\text { Ligand } 1 \\
(\mathrm{CXCL} 1)\end{array}$ & Ovary & $\mathrm{miR}-200 \mathrm{a} / \mathrm{b}$ & $\begin{array}{l}\text { Pro-Angiogenic Chemokine } \\
\text { For CXCR2; Plays a Role } \\
\text { in Inflammation and as } \\
\text { a Chemoattractiant for } \\
\text { Neutrophils }\end{array}$ & {$[50]$} \\
\hline
\end{tabular}

(Continued) 


\begin{tabular}{|c|c|c|c|c|}
\hline $\begin{array}{l}\text { Direct targets of the } \\
\text { miR-200 family }\end{array}$ & Cell types & $\begin{array}{l}\text { Targeted by which } \\
\text { miR-200 family } \\
\text { member(s) }\end{array}$ & Functions of the targets & References \\
\hline $\begin{array}{l}\text { Cofilin 2 } \\
\text { (CFL2) }\end{array}$ & $\begin{array}{l}\text { Breast, Cervix, } \\
\text { Esophagus }\end{array}$ & $\mathrm{miR}-200 \mathrm{~b} / \mathrm{a} / 429$ & $\begin{array}{l}\text { Involved in the Regulation of } \\
\text { Actin-Filament Dynamics; Can } \\
\text { Bind Both G- and F-actin } \\
\end{array}$ & $\begin{array}{l}{[67,117,} \\
118]\end{array}$ \\
\hline $\begin{array}{l}\text { V-Crk Avian Sarcoma Virus CT10 } \\
\text { Oncogene Homolog-like } \\
\text { (CRKL) }\end{array}$ & Breast & miR-200b & $\begin{array}{l}\text { Activates the Ras and Jun } \\
\text { Kinase Signaling Pathways }\end{array}$ & {$[67]$} \\
\hline $\begin{array}{l}\text { Cyclin-Dependent Kinase } 2 \\
\text { (CDK2) }\end{array}$ & Esophagus & miR-200b & $\begin{array}{l}\text { Phosphorylates Cancer Related } \\
\text { Proteins (CTNNB1, RB1, TP53, } \\
\text { MYC) }\end{array}$ & [117] \\
\hline $\begin{array}{l}\text { Cyclin-Dependent Kinase } \\
\text { Inhibitor 1B } \\
\text { (CDKN1B) }\end{array}$ & Colon & miR-200b & $\begin{array}{l}\text { Controls Cell Cycle Progression } \\
\text { at G1; Modulates Activation of } \\
\text { Cyclin A-CDK2, E-CDK2 and } \\
\text { D-CDK4 Complexes }\end{array}$ & {$[119]$} \\
\hline $\begin{array}{l}\text { Cyclin-Dependent Kinase } \\
\text { Inhibitor } 3 \\
(\mathrm{CDKN} 3) \\
\end{array}$ & Breast & miR-200a & $\begin{array}{l}\text { Dephosphorylates CDK2; } \\
\text { May Play a Role in Cell Cycle } \\
\text { Regulation }\end{array}$ & {$[67]$} \\
\hline $\begin{array}{l}\text { Dedicator of Cytokinesis } 4 \\
\text { (DOCK4) }\end{array}$ & Breast & $\mathrm{miR}-200 \mathrm{a} / \mathrm{b}$ & $\begin{array}{l}\text { Acts as a GEF; Involved in } \\
\text { Regulation of Adherens Junctions }\end{array}$ & {$[67]$} \\
\hline $\begin{array}{l}\text { Discoidin, CUB and LCCL } \\
\text { Domain Containing } 2 \\
\text { (DCBLD2) }\end{array}$ & Breast & miR-200b & $\begin{array}{l}\text { May be Involved in Vascular } \\
\text { Remodeling and Influence } \\
\text { Vascular Smooth Muscle Cell } \\
\text { Proliferation; Plays a Role in } \\
\text { Cell Motility }\end{array}$ & {$[67]$} \\
\hline $\begin{array}{l}\text { DNA (Cytosine-5-)- } \\
\text { Methyltransferase } 3 \text { Alpha } \\
\text { (DNMT3A) }\end{array}$ & Stomach & $\mathrm{miR}-200 \mathrm{~b} / \mathrm{c}$ & $\begin{array}{l}\text { Adds Methyl Groups to DNA; } \\
\text { Responsible for CpG Island } \\
\text { Methylation; Required to } \\
\text { Methylation of Imprinted Loci; } \\
\text { Corepresses ZBTB18 }\end{array}$ & {$[120]$} \\
\hline $\begin{array}{l}\text { DNA (Cytosine-5-)- } \\
\text { Methyltransferase } 3 \text { Beta } \\
\text { (DNMT3B) }\end{array}$ & Stomach & $\mathrm{miR}-200 \mathrm{~b} / \mathrm{c}$ & $\begin{array}{l}\text { Adds Methyl Groups to } \\
\text { DNA; Responsible for CpG } \\
\text { Island Methylation; Activates } \\
\text { BAG1; Acts as Corepressor by } \\
\text { Associating with ZHX1 }\end{array}$ & {$[120]$} \\
\hline $\begin{array}{l}\text { Down-Regulator of Transcription 1, } \\
\text { TBP-Binding (Negative Cofactor 2) } \\
\text { (DR1) }\end{array}$ & Breast & $\mathrm{miR}-200 \mathrm{a} / \mathrm{b}$ & $\begin{array}{l}\text { Can Bind DNA; Acts as } \\
\text { a Functional Repressor of } \\
\text { Transcription } \\
\end{array}$ & {$[67]$} \\
\hline $\begin{array}{l}\text { E2F Transcription Factor } 3 \\
(\mathrm{E} 2 \mathrm{~F} 3)\end{array}$ & $\begin{array}{l}\text { Kidney, } \\
\text { Prostate }\end{array}$ & miR-200c & $\begin{array}{l}\text { Transcription Factor; Activity } \\
\text { Inhibited by Rb; When not } \\
\text { Bound to Rb it Regulates Genes } \\
\text { Involved in the Cell Cycle } \\
\end{array}$ & $\begin{array}{l}{[113,121} \\
122]\end{array}$ \\
\hline $\begin{array}{l}\text { ELK3, ETS-Domain Protein } \\
\text { (SRF Accessory Protein 2) } \\
\text { (ELK3) }\end{array}$ & Breast & $\mathrm{miR}-200 \mathrm{a} / \mathrm{b}$ & $\begin{array}{l}\text { May be a Negative Regulator } \\
\text { of Transcription; Can Activate } \\
\text { Transcription with Ras, Src, } \\
\text { or Mos }\end{array}$ & {$[67]$} \\
\hline $\begin{array}{l}\text { ERBB Receptor Feedback } \\
\text { Inhibitor 1 } \\
\text { (ERRFI1) }\end{array}$ & Bladder, Breast & $\mathrm{miR}-200 \mathrm{~b} / \mathrm{c}$ & $\begin{array}{l}\text { Negative Regulator of EGFR } \\
\text { Signaling }\end{array}$ & {$[67,123]$} \\
\hline
\end{tabular}

(Continued) 


\begin{tabular}{|c|c|c|c|c|}
\hline $\begin{array}{l}\text { Direct targets of the } \\
\text { miR-200 family }\end{array}$ & Cell types & $\begin{array}{l}\text { Targeted by which } \\
\text { miR-200 family } \\
\text { member(s) }\end{array}$ & Functions of the targets & References \\
\hline $\begin{array}{l}\text { C-Ets Avian Erythroblastosis } \\
\text { Virus E26 Oncogene Homolog } 1 \\
\text { (ETS-1) }\end{array}$ & Kidney, Lung & $\mathrm{miR}-200 \mathrm{~b} / \mathrm{c}$ & $\begin{array}{l}\text { Transactivator and } \\
\text { Transrepressor; Controls the } \\
\text { Expression of Cytokine and } \\
\text { Chemokine Genes; Implicated } \\
\text { in Angiogenesis }\end{array}$ & $\begin{array}{l}{[124,125,} \\
126]\end{array}$ \\
\hline $\begin{array}{l}\text { Fas-associated Protein-Tyrosine } \\
\text { Phosphatase-1 } \\
\text { (FAP-1) }\end{array}$ & Colon, Ovary & miR-200c & $\begin{array}{l}\text { Tyrosine Phosphatase That } \\
\text { Negatively Regulates FAS- } \\
\text { induced Apoptosis and } \\
\text { NGFR-mediated Pro-apoptotic } \\
\text { Signaling }\end{array}$ & {$[74]$} \\
\hline $\begin{array}{l}\text { Fermitin Family Member } 2 \\
\text { (Kindlin-2) } \\
\text { (FERMT2) }\end{array}$ & Esophagus & miR-200b & $\begin{array}{l}\text { Scaffolding Protein that } \\
\text { Enhances TLN1/2-mediated } \\
\text { Integrin Activation; } \\
\text { Required for Focal } \\
\text { Adhesion Assembly } \\
\end{array}$ & {$[117]$} \\
\hline $\begin{array}{l}\text { Fibronectin } 1 \\
\text { (FN1) }\end{array}$ & $\begin{array}{l}\text { Breast, } \\
\text { Endometrium }\end{array}$ & miR-200c & $\begin{array}{l}\text { Involved in Cell Adhesion, } \\
\text { Motility, Wound Healing, and } \\
\text { Shape by Binding Collagen, } \\
\text { Fibrin, Heparin, DNA, and } \\
\text { Actin }\end{array}$ & {$[127]$} \\
\hline $\begin{array}{l}\text { Fibulin } 5 \\
\text { (FBLN5) }\end{array}$ & Muscle & miR-200c & $\begin{array}{l}\text { Secreted ECM Protein; } \\
\text { Promotes Adhesion of } \\
\text { Endothelial Cells }\end{array}$ & {$[128]$} \\
\hline $\begin{array}{l}\text { FMS-Related Tyrosine Kinase } 1 \\
\text { (FLT1, VEGFR1) }\end{array}$ & Lung & $\mathrm{miR}-200 \mathrm{~b} / \mathrm{c}$ & $\begin{array}{l}\text { Receptor Tyrosine Kinase; } \\
\text { Binds VEGF-A, VEGF-b, and } \\
\text { PGF to Regulate Angiogenesis, } \\
\text { Cell Survival, Migration, and } \\
\text { Invasion }\end{array}$ & {$[46,49]$} \\
\hline $\begin{array}{l}\text { Formin Homology } 2 \text { Domain } \\
\text { Containing } 1 \\
\text { (FHOD1) }\end{array}$ & Breast & miR-200c & $\begin{array}{l}\text { Required for the Assembly } \\
\text { of Stress Fibers; Dependent } \\
\text { Upon Rho/ROCK for its } \\
\text { Activity }\end{array}$ & {$[56]$} \\
\hline $\begin{array}{l}\text { GATA Binding Protein } 2 \\
\text { (GATA2) }\end{array}$ & Kidney & miR-200b & $\begin{array}{l}\text { Zinc-Finger Transcription } \\
\text { Factor; Involved in the } \\
\text { Development and Proliferation } \\
\text { of Hematopoietic and } \\
\text { Endocrine Cells }\end{array}$ & {$[129]$} \\
\hline $\begin{array}{l}\text { GATA Binding Protein } 4 \\
\text { (GATA4) }\end{array}$ & $\begin{array}{l}\text { Heart, Kidney, } \\
\text { Muscle }\end{array}$ & $\mathrm{miR}-200 \mathrm{~b} / \mathrm{c}$ & $\begin{array}{l}\text { Zinc-Finger Transcription } \\
\text { Factor; Involved in } \\
\text { Embryogenesis and in } \\
\text { Myocardial Differentiation } \\
\text { and Function }\end{array}$ & {$[130,131]$} \\
\hline $\begin{array}{l}\text { Guanine Nucleotide Bind } \\
\text { Protein, Alpha Inhibiting Activity } \\
\text { Polypeptide } \\
\text { (GNAI3) }\end{array}$ & Breast & $\mathrm{miR}-200 \mathrm{a} / \mathrm{b}$ & $\begin{array}{l}\text { Reduces Adenylyl Cyclase } \\
\text { Activity }\end{array}$ & {$[67]$} \\
\hline
\end{tabular}

(Continued) 


\begin{tabular}{|c|c|c|c|c|}
\hline $\begin{array}{l}\text { Direct targets of the } \\
\text { miR-200 family }\end{array}$ & Cell types & $\begin{array}{l}\text { Targeted by which } \\
\text { miR-200 family } \\
\text { member(s) }\end{array}$ & Functions of the targets & References \\
\hline $\begin{array}{l}\text { Hermansky-Pudlak Syndrome } 5 \\
\text { (HPS5) }\end{array}$ & Breast & $\mathrm{miR}-200 \mathrm{a} / \mathrm{b}$ & $\begin{array}{l}\text { May Regulate Synthesis and } \\
\text { Function of Lysosomes and } \\
\text { Highly Specialized Organelles; } \\
\text { Regulates Intracellular } \\
\text { Trafficking in Fibroblasts }\end{array}$ & [67] \\
\hline $\begin{array}{l}\text { Inhibitor of Kappa Light } \\
\text { Polypeptide Gene Enhancer in } \\
\text { B-cells, Kinase } \beta \\
\text { (IKK } \beta, \text { IкBKB) }\end{array}$ & $\begin{array}{l}\text { Endometrium, } \\
\text { Muscle }\end{array}$ & miR-200c & 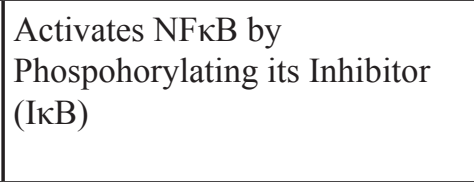 & {$[132,133]$} \\
\hline $\begin{array}{l}\text { Interleukin } 8 \\
\text { (IL8) }\end{array}$ & Ovary & $\mathrm{miR}-200 \mathrm{a} / \mathrm{b}$ & $\begin{array}{l}\text { Potent Angiogenic/Chemotactic } \\
\text { Factor }\end{array}$ & {$[50]$} \\
\hline $\begin{array}{l}\text { Jagged } 1 \\
\text { (JAG1) }\end{array}$ & $\begin{array}{l}\text { Breast, } \\
\text { Pancreas }\end{array}$ & miR-200c/141 & $\begin{array}{l}\text { Ligand for Notch 1; Involved in } \\
\text { Hematopoiesis }\end{array}$ & {$[134]$} \\
\hline $\begin{array}{l}\text { JAZF Zinc Finger } 1 \\
\text { (JAZF1) }\end{array}$ & Breast & miR-200b & Transcriptional Repressor & {$[67]$} \\
\hline $\begin{array}{l}\text { C-Jun Proto-Oncogene } \\
\text { (JUN) }\end{array}$ & Breast & miR-200b & $\begin{array}{l}\text { Complexes with c-Fos to } \\
\text { Form the AP-1 Transcription } \\
\text { Factor }\end{array}$ & [67] \\
\hline $\begin{array}{l}\text { Kelch-Like ECH-Associated } \\
\text { Protein } 1 \\
\text { (KEAP1) }\end{array}$ & Breast & miR-200a & $\begin{array}{l}\text { Part of E3 Ligase Complex } \\
\text { Involved in Nrf2 Degradation }\end{array}$ & {$[135]$} \\
\hline $\begin{array}{l}\text { Kinase Insert Domain Receptor } \\
\text { (KDR, VEGFR2) }\end{array}$ & Kidney, Lung & $\mathrm{miR}-200 \mathrm{~b} / \mathrm{c}$ & $\begin{array}{l}\text { Receptor Tyrosine Kinase; } \\
\text { Binds VEGF-A, VEGF-C, } \\
\text { and VEGF-D to Regulate } \\
\text { Angiogenesis, Vascular } \\
\text { Development, and Embryonic } \\
\text { Hematopoiesis }\end{array}$ & $\begin{array}{l}{[46,48,125,} \\
129]\end{array}$ \\
\hline $\begin{array}{l}\text { Kruppel-Like Factor } 9 \\
\text { (KLF9) }\end{array}$ & Endometrium & miR-200c & $\begin{array}{l}\text { Transcription Factor; Binds } \\
\text { GC Elements in Promoters; } \\
\text { Activates when Bound Tandem } \\
\text { Repeated GC; Inhibits When } \\
\text { Bound Only One GC Box }\end{array}$ & {$[132]$} \\
\hline $\begin{array}{l}\text { Leptin Receptor } \\
\text { (LEPR) }\end{array}$ & $\begin{array}{l}\text { Breast, } \\
\text { Endometrium }\end{array}$ & miR-200c & $\begin{array}{l}\text { Stimulates Gene Transcription } \\
\text { Through STATs; Involved in Fat } \\
\text { Metabolism and Hematopoiesis }\end{array}$ & {$[127]$} \\
\hline $\begin{array}{l}\text { Leucine-rich Repeat Containing } \\
\text { G Protein-coupled Receptor } 4 \\
\text { (LGR4) }\end{array}$ & Breast & miR-200a & $\begin{array}{l}\text { Receptor for R-spondins that are } \\
\text { Involved in Wnt Signaling }\end{array}$ & [67] \\
\hline $\begin{array}{l}\text { Lipoma HMGIC Fusion Partner } \\
\text { (LHFP) }\end{array}$ & Breast & miR-200b & $\begin{array}{l}\text { Fused to the High-mobility } \\
\text { Group Gene HMGA2 in Many } \\
\text { Lipomas }\end{array}$ & {$[67]$} \\
\hline $\begin{array}{l}\text { Low-Density Lipoprotein } \\
\text { Receptor-Related Protein } 1 \\
\text { (LRP1) }\end{array}$ & Breast, Cervix & miR-200b/a/429 & $\begin{array}{l}\text { Involved in Intracellular } \\
\text { Signaling, Lipid Homeostasis, } \\
\text { and Clearance of Apoptotic } \\
\text { Cells via Endocytosis and } \\
\text { Phagocytosis }\end{array}$ & {$[118]$} \\
\hline
\end{tabular}

(Continued) 


\begin{tabular}{|c|c|c|c|c|}
\hline $\begin{array}{l}\text { Direct targets of the } \\
\text { miR-200 family }\end{array}$ & Cell types & $\begin{array}{l}\text { Targeted by which } \\
\text { miR-200 family } \\
\text { member(s) }\end{array}$ & Functions of the targets & References \\
\hline $\begin{array}{l}\text { Mastermind-Like } 2 \\
\text { (MAML2) }\end{array}$ & $\begin{array}{l}\text { Breast, } \\
\text { Pancreas }\end{array}$ & $\mathrm{miR}-200 \mathrm{c} / 141$ & $\begin{array}{l}\text { Transcriptional Coactivator } \\
\text { for Notch Proteins; Amplifies } \\
\text { Notch-induced Transcription of } \\
\text { HES1 }\end{array}$ & {$[134]$} \\
\hline $\begin{array}{l}\text { Mastermind-Like } 3 \\
\text { (MAML3) }\end{array}$ & $\begin{array}{l}\text { Breast, } \\
\text { Pancreas }\end{array}$ & $\mathrm{miR}-200 \mathrm{c} / 141$ & $\begin{array}{l}\text { Transcriptional Coactivator } \\
\text { for Notch Proteins; Amplifies } \\
\text { Notch-induced Transcription of } \\
\text { HES1 }\end{array}$ & {$[134]$} \\
\hline $\begin{array}{l}\text { Matrin 3 } \\
\text { (MATR3) }\end{array}$ & Adrenal Gland & miR-200b & $\begin{array}{l}\text { Nuclear Matrix Protein; } \\
\text { Interacts With Other Nuclear } \\
\text { Proteins and Regulates } \\
\text { Transcription }\end{array}$ & {$[136]$} \\
\hline $\begin{array}{l}\text { Mitogen-Activated Protein } \\
\text { Kinase } 14 \\
\text { (MAPK14,p38 })\end{array}$ & Ovary & miR-200a/141 & $\begin{array}{l}\text { Mitogen Activated Kinase; } \\
\text { Involved in the Regulation } \\
\text { of Processes such as the } \\
\text { Cell Cycle, Reponse to } \\
\text { Stress, Protein Turnover, and } \\
\text { Endocytosis }\end{array}$ & {$[137]$} \\
\hline $\begin{array}{l}\text { Mitogen-activated Protein Kinase } \\
\text { Kinase } 4 \\
\text { (MAP2K4) }\end{array}$ & Breast & miR-200a & $\begin{array}{l}\text { Required for Maintaining } \\
\text { Peripheral Lymphoid } \\
\text { Homeostasis; Phosphorylates } \\
\text { Downstream MAPK Targets }\end{array}$ & {$[67]$} \\
\hline $\begin{array}{l}\text { Mitogen-activated Protein Kinase } \\
\text { Kinase Kinase } 1 \\
\text { (MEKK1) }\end{array}$ & Breast & miR-200b & $\begin{array}{l}\text { Mediates Cold, Salt, Cadmium } \\
\text { and Wound Stress Signaling; } \\
\text { Phosphorylates MEK1 }\end{array}$ & {$[67]$} \\
\hline $\begin{array}{l}\text { Mitogen-activated Protein Kinase } \\
\text { Kinase Kinase } 7 \\
\text { (MAP3K7) }\end{array}$ & Breast & $\mathrm{miR}-200 \mathrm{a} / \mathrm{b}$ & $\begin{array}{l}\text { Controls a Variety of } \\
\text { Cell Functions Including } \\
\text { Transcription and Apoptosis; } \\
\text { Involved in Response to } \\
\text { Environmental Stresses }\end{array}$ & {$[67]$} \\
\hline $\begin{array}{l}\text { Moesin } \\
(\mathrm{MSN})\end{array}$ & $\begin{array}{l}\text { Breast, } \\
\text { Endometrium }\end{array}$ & $\mathrm{miR}-200 \mathrm{~b} / \mathrm{c}$ & $\begin{array}{l}\text { Regulates Actin Localization } \\
\text { and Cross-Linking to the } \\
\text { Plasma Membrane; Localized to } \\
\text { Filopodia }\end{array}$ & {$[67,43,127]$} \\
\hline $\begin{array}{l}\text { Myoferlin } \\
\text { (MYOF) }\end{array}$ & Breast & miR-200b & $\begin{array}{l}\text { Associates with both Plasma } \\
\text { and Nuclear Membranes; } \\
\text { Involved in Calcium-mediated } \\
\text { Membrane Fusion Events }\end{array}$ & {$[67]$} \\
\hline $\begin{array}{l}\text { Myosin Light Chain Kinase } \\
\text { (MYLK) }\end{array}$ & Breast & miR-200b & $\begin{array}{l}\text { Implicated in Smooth Muscle } \\
\text { Contraction; Phosphorylates } \\
\text { Myosin Light Chains; Involved } \\
\text { in the Inflammatory Response, } \\
\text { Cell Motility, and Cell } \\
\text { Morphology }\end{array}$ & {$[67]$} \\
\hline
\end{tabular}

(Continued) 


\begin{tabular}{|c|c|c|c|c|}
\hline $\begin{array}{l}\text { Direct targets of the } \\
\text { miR-200 family }\end{array}$ & Cell types & $\begin{array}{l}\text { Targeted by which } \\
\text { miR-200 family } \\
\text { member(s) }\end{array}$ & Functions of the targets & References \\
\hline $\begin{array}{l}\text { Myosin Phosphatase Rho } \\
\text { Interacting Protein } \\
\text { (MPRIP) }\end{array}$ & Breast & miR-200b & $\begin{array}{l}\text { Targets Myosin Phosphatase } \\
\text { to the Actin Cytoskeleton; } \\
\text { Required for RhoA and } \\
\text { ROCK1 Actin Cytoskeleton } \\
\text { Regulation }\end{array}$ & {$[67]$} \\
\hline $\begin{array}{l}\text { Myosin Phosphatase Target } \\
\text { Subunit } 1 \\
\text { (MYPT1) }\end{array}$ & Breast & $\mathrm{miR}-200 \mathrm{a} / \mathrm{b}$ & $\begin{array}{l}\text { A Regulatory Subunit of Myosin } \\
\text { Phosphatase } 1\end{array}$ & {$[67]$} \\
\hline $\begin{array}{l}\text { Neuroepithelial Cell } \\
\text { Transforming } 1 \\
\text { (NET1) }\end{array}$ & Breast & miR-200b & $\begin{array}{l}\text { Guanine Nucleotide Exchange } \\
\text { Factor (GEF) for RhoA; May } \\
\text { be Involved in Activation of } \\
\text { SAPK/JNK pathway }\end{array}$ & {$[67]$} \\
\hline $\begin{array}{l}\text { Neurotrophic Tyrosine Kinase, } \\
\text { Receptor, Type } 2(\operatorname{Trk} \beta) \\
\text { (NTRK2) }\end{array}$ & $\begin{array}{l}\text { Breast, } \\
\text { Endometrium }\end{array}$ & miR-200c & $\begin{array}{l}\text { RTK Involved in the Regulation } \\
\text { of Differentiation, Proliferation, } \\
\text { Survival, Learning, Memory, } \\
\text { and Apoptotic Signaling } \\
\text { Cascades }\end{array}$ & {$[77,127]$} \\
\hline $\begin{array}{l}\text { Neurotrophin } 3 \\
\text { (NTF3) }\end{array}$ & Breast & miR-200c & $\begin{array}{l}\text { Controls Survival and } \\
\text { Differentiation of Neurons; } \\
\text { TrkB Ligand }\end{array}$ & {$[77,127]$} \\
\hline $\begin{array}{l}\text { Notch 1 } \\
\text { (NOTCH1) }\end{array}$ & Breast & miR-200b & $\begin{array}{l}\text { Involved in Controlling Cell } \\
\text { Fate }\end{array}$ & {$[67]$} \\
\hline $\begin{array}{l}\text { One Cut Homeobox } 2 \\
\text { (ONECUT2) }\end{array}$ & Colon & miR-429 & $\begin{array}{l}\text { Transcriptional Activator; } \\
\text { Involved in Melanocyte and } \\
\text { Hepatocyte Differentiation; } \\
\text { Activates the Transcription of } \\
\text { Liver Specific Genes }\end{array}$ & {$[40]$} \\
\hline $\begin{array}{l}\text { PCNA-Associated Factor } 15 \\
\text { (PAF, KIAA0101) }\end{array}$ & Esophagus & miR-200b & $\begin{array}{l}\text { PCNA-Binding Protein that } \\
\text { Acts as a Regulator of } \\
\text { DNA Repair During } \\
\text { Replication }\end{array}$ & {$[117]$} \\
\hline $\begin{array}{l}\text { Peptidylprolyl Cis/Trans } \\
\text { Isomerase, NIMA-Interacting } 1 \\
\text { (PIN1) }\end{array}$ & Breast & $\mathrm{miR}-200 \mathrm{~b} / \mathrm{c}$ & $\begin{array}{l}\text { Regulates Mitosis; Catalyzes } \\
\text { pSer/Thr-Pro Cis/Trans } \\
\text { Isomerizations; Down- } \\
\text { regulates Kinase Activity of } \\
\text { BTK; Required for RAF1 } \\
\text { Dephosphorylation }\end{array}$ & {$[78,138]$} \\
\hline $\begin{array}{l}\text { Peroxiredoxin } 2 \\
\text { (PRDX2) }\end{array}$ & Lung & miR-200c & $\begin{array}{l}\text { Enzyme that Reduces Peroxide } \\
\text { and Alkyl Hydroperoxides; } \\
\text { Stabilizes Hemoglobin }\end{array}$ & [139] \\
\hline $\begin{array}{l}\text { Phorbol-12-Myristate-13-Acetate- } \\
\text { Induced Protein } 1 \\
\text { (PMAIP1, NOXA) }\end{array}$ & Breast & miR-200c & $\begin{array}{l}\text { Promotes Activation of } \\
\text { Caspases and Apoptosis; } \\
\text { Contributes to p53- } \\
\text { dependent Apoptosis } \\
\text { After Radiation; Promotes } \\
\text { MCL1 Degradation }\end{array}$ & {$[75]$} \\
\hline
\end{tabular}

(Continued) 


\begin{tabular}{|c|c|c|c|c|}
\hline $\begin{array}{l}\text { Direct targets of the } \\
\text { miR-200 family }\end{array}$ & Cell types & $\begin{array}{l}\text { Targeted by which } \\
\text { miR-200 family } \\
\text { member(s) }\end{array}$ & Functions of the targets & References \\
\hline $\begin{array}{l}\text { Phosphatase and Tensin Homolog } \\
\text { (PTEN) }\end{array}$ & $\begin{array}{l}\text { Endometrium, } \\
\text { Pituitary Gland }\end{array}$ & $\mathrm{miR}-200 \mathrm{a} / \mathrm{c}$ & $\begin{array}{l}\text { Tumor Suppressor; } \\
\text { Dephosphorylates Tyrosine-, } \\
\text { Serine-, and Threonine- } \\
\text { Phosphorylated Proteins; } \\
\text { Antagonizes PI3K-Akt/PKB } \\
\text { Signaling Pathway }\end{array}$ & {$[140,141]$} \\
\hline $\begin{array}{l}\text { Phospholipase C, gamma } 1 \\
\text { (PLCG1) }\end{array}$ & Breast & $\mathrm{miR}-200 \mathrm{~b} / \mathrm{c} / 429$ & $\begin{array}{l}\text { Forms } \mathrm{IP}_{3} \text { and } \mathrm{DAG} \text {; Involved } \\
\text { in Proliferation, Apoptosis, and } \\
\text { EGFR-driven Invasion }\end{array}$ & {$[67,73]$} \\
\hline $\begin{array}{l}\text { Polycystic Kidney Disease } 1 \\
\text { (PKD1) }\end{array}$ & Kidney & $\mathrm{miR}-200 \mathrm{a} / \mathrm{b}$ & $\begin{array}{l}\text { Regulator of Calcium Permeable } \\
\text { Cation Channels and Intracellular } \\
\text { Calcium Homeostasis; Involved } \\
\text { in Cell-Cell and Cell-Matrix } \\
\text { Interactions }\end{array}$ & [142] \\
\hline $\begin{array}{l}\text { Potassium Channel } \\
\text { Tetramerization Domain } \\
\text { Containing } 2 \\
(\text { KCTD2) }\end{array}$ & Breast & $\mathrm{miR}-200 \mathrm{a} / \mathrm{b}$ & $\begin{array}{l}\text { Thought to be Involved in } \\
\text { Transcriptional Regulation via } \\
\text { Control of Chromatin Structure } \\
\text { and Function }\end{array}$ & {$[67]$} \\
\hline $\begin{array}{l}\text { Prominin } 1 \\
\text { (CD133) }\end{array}$ & Brain & miR-200b & $\begin{array}{l}\text { Binds Cholesterol; May Play } \\
\text { a Role in Apical Plasma } \\
\text { Membrane Organization of } \\
\text { Epithelial Cells; Regulates } \\
\text { MAPK and Akt Signaling }\end{array}$ & {$[143]$} \\
\hline $\begin{array}{l}\text { Protein Kinase C alpha } \\
\text { (PRKCA) }\end{array}$ & Breast, Lung & miR-200b & $\begin{array}{l}\text { Serine- and Threonine-Specific } \\
\text { Kinase; Shown to Play a Role in } \\
\text { Cell Adhesion, Transformation, } \\
\text { Migration, and the Cell Cycle } \\
\text { Checkpoint }\end{array}$ & {$[42,66]$} \\
\hline $\begin{array}{l}\text { Protein Phosphatase } \mathrm{Mg}^{2+} / \mathrm{Mn}^{2+} \\
\text { dependent, } 1 \mathrm{~F} \\
\text { (PPM1F) }\end{array}$ & Breast & miR-200c & $\begin{array}{l}\text { Dephosphorylates and } \\
\text { Deactivates CaM-kinase II; } \\
\text { Mediates Caspase-Dependent } \\
\text { Apoptosis }\end{array}$ & {$[56]$} \\
\hline $\begin{array}{l}\text { RAB18, Member RAS } \\
\text { Oncogene Family } \\
\text { (RAB18) }\end{array}$ & Breast & miR-200b & $\begin{array}{l}\text { Involved in Endocytosis and } \\
\text { Recycling }\end{array}$ & {$[144]$} \\
\hline $\begin{array}{l}\text { RAB21, Member RAS } \\
\text { Oncogene Family } \\
\text { (RAB21) }\end{array}$ & Breast & miR-200b & $\begin{array}{l}\text { Involved in the Control of } \\
\text { Integrin Trafficking }\end{array}$ & {$[144]$} \\
\hline $\begin{array}{l}\text { RAB23, Member RAS } \\
\text { Oncogene Family } \\
\text { (RAB23) }\end{array}$ & Breast & miR-200b & $\begin{array}{l}\text { Antagonist of Sonic Hedgehog } \\
\text { Signaling }\end{array}$ & {$[144]$} \\
\hline $\begin{array}{l}\text { RAB3B, Member RAS } \\
\text { Oncogene Family } \\
\text { (RAB3B) }\end{array}$ & Breast & miR-200b & Promotes Cancer Cell Survival & {$[144]$} \\
\hline $\begin{array}{l}\text { Rho-Associated, Coiled-Coil } \\
\text { Containing Protein Kinase } 2 \\
\text { (ROCK2) }\end{array}$ & Breast, Liver & $\mathrm{miR}-200 \mathrm{~b} / \mathrm{c}$ & $\begin{array}{l}\text { Kinase Activated by Rho } \\
\text { GTPases; Regulates Actin } \\
\text { Cytoskeleton Organization and } \\
\text { Cell Polarity }\end{array}$ & {$[67,145]$} \\
\hline
\end{tabular}

(Continued) 


\begin{tabular}{|c|c|c|c|c|}
\hline $\begin{array}{l}\text { Direct targets of the } \\
\text { miR-200 family }\end{array}$ & Cell types & $\begin{array}{l}\text { Targeted by which } \\
\text { miR-200 family } \\
\text { member(s) }\end{array}$ & Functions of the targets & References \\
\hline $\begin{array}{l}\text { Rho Family GTPase } 3 \\
\text { (RND3) }\end{array}$ & Colon & miR-200b & $\begin{array}{l}\text { Little Known; Binds GTP, but } \\
\text { Lacks GTPase Activity; May } \\
\text { Act as Negative Regulator of } \\
\text { Cytoskeletal Organization }\end{array}$ & [119] \\
\hline $\begin{array}{l}\text { Rho GTPase Activating Protein } 19 \\
\text { (ARHGAP19) }\end{array}$ & $\begin{array}{l}\text { Breast, } \\
\text { Endometrium }\end{array}$ & miR-200c & $\begin{array}{l}\text { Function Relatively Unknown; } \\
\text { GTPase Activator for the Rho- } \\
\text { GTPases }\end{array}$ & {$[127]$} \\
\hline $\begin{array}{l}\text { Rho GTPase Activating Protein } \\
29 \\
\text { (ARHGAP29) }\end{array}$ & Breast & miR-200b & $\begin{array}{l}\text { GTPase Activator for the } \\
\text { Rho-GTPases; Strong Activity } \\
\text { Towards RhoA; Weak Activity } \\
\text { Towards Rac1 and Cdc42 }\end{array}$ & {$[67]$} \\
\hline $\begin{array}{l}\text { Rho Guanine Nucleotide } \\
\text { Exchange Factor (GEF) } 3 \\
\text { (ARHGEF3) }\end{array}$ & Breast & miR-200b & $\begin{array}{l}\text { Acts as a Guanine Nucleotide } \\
\text { Exchange Factor (GEF) for } \\
\text { RhoA and RhoB GTPases }\end{array}$ & {$[67]$} \\
\hline $\begin{array}{l}\text { Ring Finger Protein } 38 \\
\text { (RNF38) }\end{array}$ & Breast & miR-200a & $\begin{array}{l}\text { Acts as an E3 Ubiquitin-protein } \\
\text { Ligase }\end{array}$ & {$[67]$} \\
\hline $\begin{array}{l}\text { Sec23 Homolog A } \\
(\text { SEC23A) }\end{array}$ & Breast, Cervix & miR-200b/a/429 & $\begin{array}{l}\text { Metastasis Suppressor; } \\
\text { Component of COPII Vesicles; } \\
\text { Involved in Anterograde } \\
\text { Transport }\end{array}$ & {$[67,72]$} \\
\hline $\begin{array}{l}\text { SHC SH2-Domain Binding } \\
\text { Protein 1 } \\
\text { (SHCBP1) }\end{array}$ & Breast & miR-200b & $\begin{array}{l}\text { May Play a Role in Cell } \\
\text { Proliferation, Growth, and } \\
\text { Differentiation; Acts as a Positive } \\
\text { Regulator of FGF Signaling in } \\
\text { Neural Progenitor Cells } \\
\end{array}$ & {$[67]$} \\
\hline $\begin{array}{l}\text { Single-Minded Family BHLH } \\
\text { Transcription Factor 2, Short } \\
\text { Isoform } \\
\text { (SIM2-s) }\end{array}$ & Brain & miR-200a & $\begin{array}{l}\text { Transcription Factor That May } \\
\text { be a Master Gene of CNS } \\
\text { Development }\end{array}$ & {$[146]$} \\
\hline $\begin{array}{l}\text { Signal Transducer and Activator } \\
\text { of Transcription } 5 \mathrm{~b} \\
\text { (STAT5B) }\end{array}$ & Kidney & miR-200a & $\begin{array}{l}\text { Acts as a Transcriptional } \\
\text { Activator once Phosphorylated; } \\
\text { Involved in TCR Signaling, } \\
\text { Apoptosis, Adult Mammary } \\
\text { Gland Development, and Sexual } \\
\text { Dimorphism of Liver Gene } \\
\text { Expression } \\
\end{array}$ & {$[147]$} \\
\hline $\begin{array}{l}\text { SRY (Sec Determining Region } \\
\text { Y)-Box } 2 \\
\text { (SOX2) }\end{array}$ & Colon, Kidney & miR-200c & $\begin{array}{l}\text { Transcription Factor; } \\
\text { Involved in the Regulation } \\
\text { of Embryonic Development } \\
\text { and in Determination of Cell } \\
\text { Fate; Required for Stem Cell } \\
\text { Maintanence }\end{array}$ & {$[121,148]$} \\
\hline $\begin{array}{l}\text { SUZ12 Polycomb Repressive } \\
\text { Complex } 2 \text { Subunit } \\
\text { (SUZ12) }\end{array}$ & Breast, Liver & $\mathrm{miR}-200 \mathrm{~b} / \mathrm{c}$ & $\begin{array}{l}\text { Polycomb Group Protein } \\
\text { Involved in Silencing Gene } \\
\text { Targets by Methylation of } \\
\text { Histone H3 }\end{array}$ & $\begin{array}{l}{[44,145,} \\
149]\end{array}$ \\
\hline
\end{tabular}

(Continued) 


\begin{tabular}{|c|c|c|c|c|}
\hline $\begin{array}{l}\text { Direct targets of the } \\
\text { miR-200 family }\end{array}$ & Cell types & $\begin{array}{l}\text { Targeted by which } \\
\text { miR-200 family } \\
\text { member(s) }\end{array}$ & Functions of the targets & References \\
\hline $\begin{array}{l}\text { Tissue Inhibitor of } \\
\text { Metalloproteinase } 2 \\
\text { (TIMP2) }\end{array}$ & Muscle & miR-200c & $\begin{array}{l}\text { Inhibitor of Matrix } \\
\text { Metalloproteinases; Suppresses } \\
\text { Proliferation of Endothelial } \\
\text { Cells }\end{array}$ & [128] \\
\hline $\begin{array}{l}\text { Transcription Factor } 12 \\
\text { (TCF12) }\end{array}$ & Breast & miR-200b & $\begin{array}{l}\text { Transcriptional Regulator; } \\
\text { Involved in Neuronal } \\
\text { Differentiation }\end{array}$ & {$[67]$} \\
\hline $\begin{array}{l}\text { Transforming Growth Factor } \beta 2 \\
\text { (TGFß2) }\end{array}$ & Colon & $\operatorname{miR}-141$ & $\begin{array}{l}\text { Suppressor of IL-2 Dependent } \\
\text { T-cell Growth; Activator of } \\
\text { EMT }\end{array}$ & {$[65]$} \\
\hline $\begin{array}{l}\text { Transmembrane Protein } 209 \\
\text { (TMEM209) }\end{array}$ & Breast & miR-200a/b & $\begin{array}{l}\text { Nuclear Envelope Protein; Plays } \\
\text { a Role in Promotion of Cell } \\
\text { Proliferation }\end{array}$ & {$[67]$} \\
\hline $\begin{array}{l}\text { Dynamin Binding Protein } \\
\text { (DNMBP, TUBA) }\end{array}$ & Breast & $\mathrm{miR}-200 \mathrm{a} / \mathrm{b}$ & $\begin{array}{l}\text { Links Dynamin with Actin- } \\
\text { regulating Proteins; Plays a Role } \\
\text { in Regulation of Cell Junctions }\end{array}$ & {$[67]$} \\
\hline $\begin{array}{l}\text { Tubulin, } \beta 3 \text { class III } \\
\text { (TUBB3) }\end{array}$ & $\begin{array}{l}\text { Endometrium, } \\
\text { Ovary }\end{array}$ & miR-200c & $\begin{array}{l}\text { Major Constituent of } \\
\text { Microtubules; Plays a Role } \\
\text { in Proper Axon Guidance and } \\
\text { Maintenance }\end{array}$ & $\begin{array}{l}{[150,151} \\
152]\end{array}$ \\
\hline $\begin{array}{l}\text { Vascular Endothelial Growth } \\
\text { Factor A } \\
\text { (VEGFA) }\end{array}$ & $\begin{array}{l}\text { Endometrium, } \\
\text { Lung, Muscle }\end{array}$ & miR-200b & $\begin{array}{l}\text { Growth Factor that Induces } \\
\text { Angiogenesis, Vasculogenesis, } \\
\text { and Endothelial Cell Growth; } \\
\text { Promotes Migration; Inhibits } \\
\text { Apoptosis }\end{array}$ & $\begin{array}{l}{[46,128} \\
132]\end{array}$ \\
\hline $\begin{array}{l}\text { WAS Protein Family, Member } 3 \\
\text { (WAVE3) }\end{array}$ & $\begin{array}{l}\text { Breast, Colon, } \\
\text { Prostate }\end{array}$ & miR-200b & $\begin{array}{l}\text { Protein Involved in Actin } \\
\text { Cytoskeleton Remodeling; } \\
\text { Required for the Control of Cell } \\
\text { Shape }\end{array}$ & {$[55]$} \\
\hline $\begin{array}{l}\text { WAS/WASL Interacting Protein } \\
\text { Family, Member } 1 \\
\text { (WIPF1) }\end{array}$ & Breast & miR-200b & $\begin{array}{l}\text { Important in Organization of } \\
\text { the Actin Cytoskeleton; Plays } \\
\text { a Role in the Formation of Cell } \\
\text { Ruffles }\end{array}$ & [67] \\
\hline $\begin{array}{l}\text { Wingless-Type MMTV } \\
\text { Integration Site Family, } \\
\text { Member 1 } \\
\text { (WNT1) }\end{array}$ & Stomach & miR-200b & $\begin{array}{l}\text { Function Relatively Unknown; } \\
\text { Ligand for the Frizzled Receptor } \\
\text { Family; Probable Role in } \\
\text { Developmental Processes }\end{array}$ & {$[153]$} \\
\hline $\begin{array}{l}\text { X-Linked Inhibitor of Apoptosis } \\
\text { (XIAP) }\end{array}$ & Stomach, Lung & $\mathrm{miR}-200 \mathrm{~b} / \mathrm{c} / 429$ & $\begin{array}{l}\text { Potent Apoptosis Suppressor; } \\
\text { Directly Binds and Inhibits } \\
\text { Caspase-3, }-7 \text {, and -9 Activity }\end{array}$ & [110] \\
\hline $\begin{array}{l}\text { Yes-Associated Protein } 1 \\
\text { (YAP1) }\end{array}$ & Breast & miR-200a & $\begin{array}{l}\text { Transcriptional Coactivator and } \\
\text { Corepressor; Effector of Hippo } \\
\text { Signaling Pathway; Regulates } \\
\text { Cell Proliferation, Death, and } \\
\text { Migration }\end{array}$ & [79] \\
\hline
\end{tabular}

(Continued) 


\begin{tabular}{|c|c|c|c|c|}
\hline $\begin{array}{l}\text { Direct targets of the } \\
\text { miR-200 family }\end{array}$ & Cell types & $\begin{array}{l}\text { Targeted by which } \\
\text { miR-200 family } \\
\text { member(s) }\end{array}$ & Functions of the targets & References \\
\hline $\begin{array}{l}\text { Zinc Finger E-box Binding } \\
\text { Homeobox } 1 \\
(\text { ZEB } 1)\end{array}$ & $\begin{array}{l}\text { Breast, Colon, } \\
\text { Cervix, Ovary }\end{array}$ & All five members & $\begin{array}{l}\text { Transcriptional Repressor of } \\
\text { E-cadherin and miR-200 Family } \\
\text { Members; Expression Promotes } \\
\text { EMT }\end{array}$ & $\begin{array}{l}{[67,61} \\
62,72]\end{array}$ \\
\hline $\begin{array}{l}\text { Zinc Finger E-box Binding } \\
\text { Homeobox } 2 \\
(\text { ZEB2, SIP1) }\end{array}$ & $\begin{array}{l}\text { Breast, Colon, } \\
\text { Cervix, Ovary }\end{array}$ & All five members & $\begin{array}{l}\text { Transcriptional Repressor of } \\
\text { E-cadherin and miR-200 Family } \\
\text { Members; Expression Promotes } \\
\text { EMT }\end{array}$ & {$[61,62,72]$} \\
\hline
\end{tabular}

Note: Only those that were confirmed to be a direct target by a luciferase reporter assay in a cell line were presented here. Targets are arranged alphabetically. Gene name is shown followed by gene abbreviation in parentheses. Cell type is the tissue origin of the cell that the luciferase reporter was performed in. Known function is the general known function of the gene.

\section{Cell Malignant Transformation and Tumor Initiation}
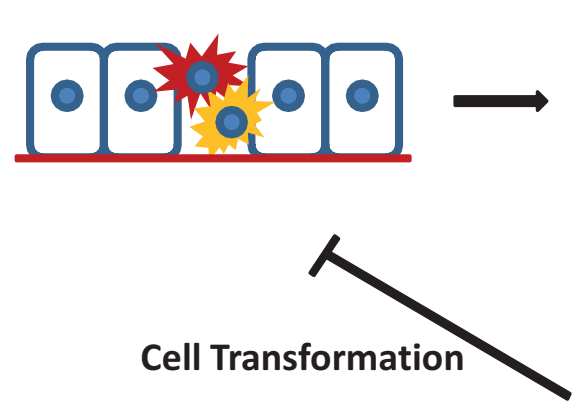

Tumor Growth, Angiogenesis, and Nearby Tissue Invasion

\section{Migration Away from Primary Tumor, Degradation of ECM and Cell Intravasation}
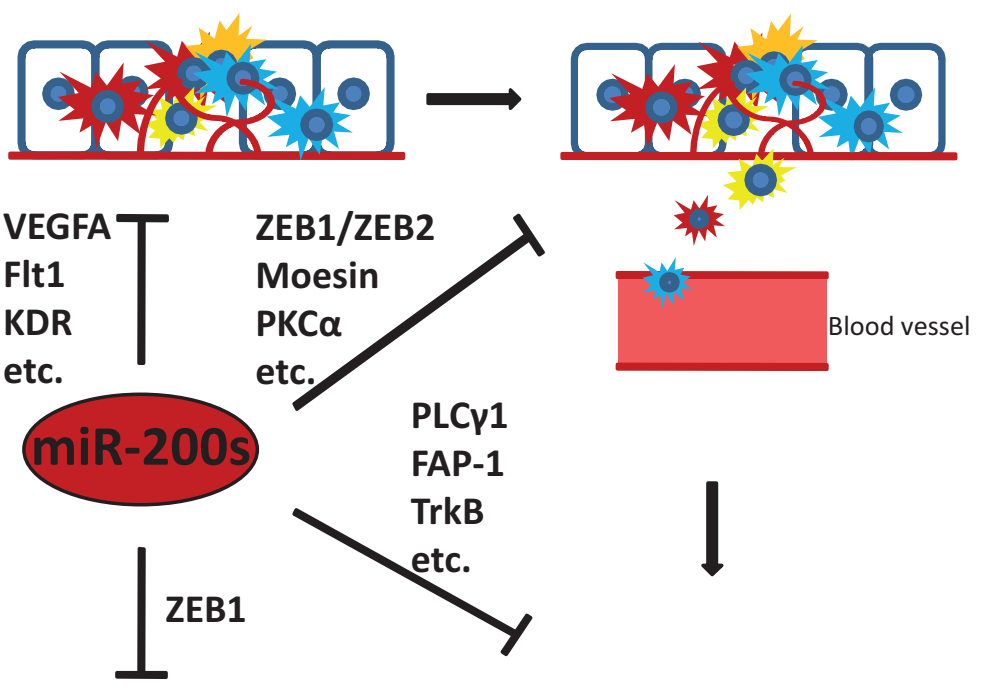

PLCY1

FAP-1

TrkB

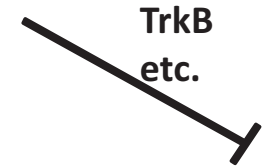

\section{Survival in Circulation}

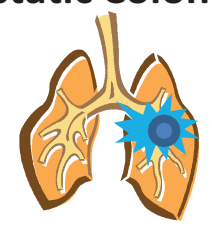

Tumor Cell Extravasation
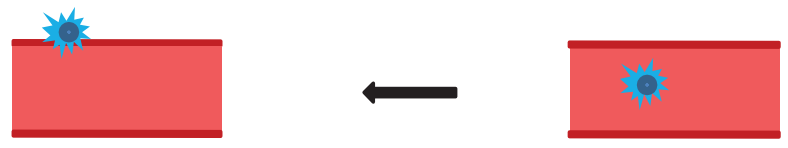

Figure 3: The miR-200s play critical roles in tumor initiation and the metastatic cascade. Some representative miR-200 targets involved in each step of the metastatic cascade are shown.

$\downarrow$ means promote $\perp$ means inhibit. 
also needed to advance our knowledge on the miR-200's role in these critical processes. Moreover, most of the research done on individual miR-200 family members focuses on miR-200b or $-200 \mathrm{c}$, therefore more work is needed on miR-200a, -141 and -429 and their individual role in cancer. Since some of the data on the role of miR200 family in cancer is controversial and cellular context dependent, it is important for future studies to tease apart which miR-200 family members act as a tumor suppressor and which may promote cancer progression. Completing these studies will lead to the discovery of more miR200 targets and ultimately the development of novel and targeted therapeutic options for the treatment of cancer.

\section{FUNDING INFORMATION}

This work was supported by the National Institutes of Health [R01ES017777 to C.Y.].

\section{CONFLICT OF INTEREST}

None declared.

\section{Abbreviations}

3囚UTR: 3区 untranslated region; 4-OHT: 4-Hydroxytamoxifen; BPDE: Benzo(a)pyrene diolepoxide; CEA: Carcinoembryonic antigen; CTCs: circulating tumor cells; DGCR8: DiGeorge syndrome critical region 8; ECM: Extracellular matrix; EMT: Epithelial-to-mesenchymal transition; HBECs: Human bronchial epithelial cells; HUVECs: Human umbilical vein endothelial cells; MBC: Metastatic breast cancer; MET: Mesenchymal-to-epithelial transition; miRNA: microRNA; mRNA: messenger RNA; NMU: $N$-Nitroso- $N$-methylurea; NSCLC: Non-small cell lung cancer; OSCC: Oral squamous cell carcinoma; pre-miRNA: precursor miRNA; pri-miRNA: primary microRNA; qPCR: Quantitative polymerase chain reaction; RISC: RNA-induced silencing complex; SCID: Severe combined immunodeficiency; TAMs: Tumor associated macrophages; TNBC: Triple negative breast cancer; Zinc finger E-box binding homeobox 1 and 2: ZEB1 and ZEB2.

\section{REFERENCES}

1. Lee RC, Feinbaum RL, Ambros V. The C. elegans heterochronic gene lin-4 encodes small RNAs with antisense complementarity to lin-14. Cell. 1993; 75:843-854.

2. Wightman B, Ha I, Ruvkun G. Posttranscriptional regulation of the heterochronic gene lin-14 by lin- 4 mediates temporal pattern formation in C. elegans. Cell. 1993; 75:855-862.

3. Lau NC, Lim LP, Weinstein EG, Bartel DP. An abundant class of tiny RNAs with probable regulatory roles in Caenorhabditis elegans. Science. 2001; 294:858-862.
4. Lagos-Quintana M, Rauhut R, Lendeckel W, Tuschl T. Identification of novel genes coding for small expressed RNAs. Science. 2001; 294:853-858.

5. Lee RC, Ambros V. An extensive class of small RNAs in Caenorhabditis elegans. Science. 2001; 294:862-864.

6. Calin GA, Dumitru CD, Shimizu M, Bichi R, Zupo S, Noch E, Aldler H, Rattan S, Keating M, Rai K, Rassenti L, Kipps T, Negrini M, et al. Frequent deletions and down-regulation of micro-RNA genes miR15 and miR16 at 13q14 in chronic lymphocytic leukemia. PNAS. 2002; 99:15524-15529.

7. Lee Y, Kim M, Han J, Yeom KH, Lee S, Baek SH, Kim VN. MicroRNA genes are transcribed by RNA polymerase II. EMBO J. 2004; 23:4051-4060.

8. Cai X, Hagedorn CH, Cullen BR. Human microRNAs are processed from capped, polyadenylated transcripts that can also function as mRNAs. RNA. 2004; 10:1957-1966.

9. Lee Y, Ahn C, Han J, Choi H, Kim J, Yim J, Lee J, Provost P, Radmark O, Kim S, Kim VN. The nuclear RNase III Drosha initiates microRNA processing. Nature. 2003; 425:415-419.

10. Han J, Lee Y, Yeom KH, Kim YK, Jin H, Kim VN. The Drosha-DGCR8 complex in primary microRNA processing. Genes Dev. 2004; 18:3016-3027.

11. Hutvágner G, McLachlan J, Pasquinelli AE, Balint E, Tuschl T, Zamore PD. A cellular function for the RNAinterference enzyme Dicer in the maturation of the let-7 small temporal RNA. Science. 2001; 293:834-838.

12. Grishok A, Pasquinelli AE, Conte D, Conte N, Li S, Parrish S, Ha I, Baillie DL, Fire A, Ruvkun G, Mello CC. Genes and mechanisms related to RNA interference regulate expression of the small temporal RNAs that control C. elegans developmental timing. Cell. 2001; 106:23-34.

13. Qin W, Shi Y, Zhao B, Yao C, Jin L, Ma J, Jin Y. miR-24 Regulates Apoptosis by Targeting the Open Reading Frame (ORF) Region of FAF1 in Cancer Cells. PloS ONE. 2010; 5:e9429.

14. Pillai RS, Bhattacharyya SN, Filipowicz W. Repression of protein synthesis by miRNAs: how many mechanisms? TRENDS Cell Biol. 2007; 17:118-126.

15. Bartel DP. MicroRNA Target Recognition and Regulatory Functions. Cell. 2009; 136:215-233.

16. Karginov FV, Cheloufi S, Chong MMW, Stark A, Smith AD, Hannon GJ. Diverse endonucleolytic cleavage sites in the mammalian transcriptome depend upon microRNAs, Drosha, and additional nucleases. Mol Cell. 2010; 38:781-788.

17. Bracken CP, Szubert JM, Mercer TR, Dinger ME, Thomson DW, Mattick JS, Michael MZ, Goodall GJ. Global analysis of the mammalian RNA degradome reveals widespread miRNA-dependent and miRNA-independent endonucleolytic cleavage. Nucleic Acids Res. 2011; 39:5658-5668.

18. Eichhorn SW, Guo H, McGeary SE, RodriquezMias RA, Shin C, Baek D, Hsu SH, Ghoshal K, Villén J, Bartel DP. mRNA Destabilization Is the Dominant Effect 
of Mammalian MicroRNAs by the Time Substantial Repression Ensues. Mol Cell. 2014; 56:104-115.

19. Baek D, Villén J, Shin C, Camargo FD, Gygi SP, Bartel DP. The impact of microRNAs on protein output. Nature. 2008; 455:64-71.

20. Selbach M, Schwanhäusser B, Thierfelder N, Fang Z, Khanin R, Rajewsky N. Widespread changes in protein synthesis induced by microRNAs. Nature. 2008; 455:58-63.

21. Brennecke J, Stark A, Russell RB, Cohen SM. Principles of MicroRNA-Target Recognition. PLoS Biol. 2005; 3:e85.

22. Carroll AP, Goodall GJ, Liu B. Understanding principles of miRNA target recognition and function through integrated biological and bioinformatics approaches. WIREs RNA. 2014; 5:361-379.

23. Friedman RC, Farh KKH, Burge CB, Bartel DP. Most mammalian mRNAs are conserved targets of microRNAs. Genome Res. 2009; 19:92-105.

24. Garzon R, Calin GA, Croce CM. MicroRNAs in cancer. Annu Rev Med. 2009; 60:167-179.

25. Nana-Sinkam SP, Croce CM. Clinical Applications for microRNAs in cancer. Clin Pharmacol Ther. 2013; 93:98-104.

26. Esquela-Kerscher A, Slack FJ. Oncomirs - microRNAs with a role in cancer. Nat Rev Cancer. 2006; 6:259-269.

27. Altuvia Y, Landgraf P, Lithwick G, Elefant N, Pfeffer S, Aravin A, Brownstein MJ, Tuschl T, Margalit H. Clustering and conservation patterns of human microRNAs. Nucleic Acids Res. 2005; 33:2697-2706.

28. Michael MZ, O’Connor SM, van Holst Pellekaan NG, Young GP, James RJ. Reduced accumulation of specific microRNAs in colorectal neoplasia. Mol Cancer Res. 2003; $1: 882-891$.

29. Neves R, Scheel C, Weinhold S, Honisch E, Iwaniuk KM, Trompeter HI, Niederacher D, Wernet P, Santourlidis S, Uhrberg M. Role of DNA methylation in miR-200c/141 cluster silencing in invasive breast cancer cells. BMC Research Notes. 2010; 3:219.

30. Castilla MÁ, Diaz-Martín J, Sarrió D, Romero-Pérez L, López-García MÁ, Vieites B, Biscuola M, RamiroFuentes S, Isacke CM, Palacios J. MicroRNA-200 family modulation in distinct breast cancer phenotypes. PLoS ONE. 2012; 7:e47709.

31. Lim YY, Wright JA, Attema JL, Gregory PA, Bert AG, Smith E, Thomas D, Lopez AF, Drew PA, KhewGoodall Y, Goodall GJ. Epigenetic modulation of the miR200 family is associated with transition to a breast cancer stem-cell-like state. J Cell Sci. 2013; 126:2256-2266.

32. Kolesnikoff N, Attema JL, Roslan S, Bert AG, Schwarz QP, Gregory PA, Goodall GJ. Specificity protein 1 (Sp1) maintains basal epithelial expression of the miR-200 family: implications for epithelial-mesenchymal transition. J Biol Chem. 2014; 289:11194-11205.

33. Kim T, Veronese A, Pichiorri F, Lee TJ, Jeon YJ, Volinia S, Pineau P, Marchio A, Palatini J, Suh SS, Alder H, Liu CG,
Dejean A, et al. P53 regulates epithelial-mesenchymal transition through microRNAs targeting ZEB1 and ZEB2. J Exp Med. 2011; 208:875-883.

34. Chang CJ, Chao CH, Xia W, Yang JY, Xiong Y, Li CW, Yu WH, Rehman SK, Hsu JL, Lee HH, Liu M, Chen CT, $\mathrm{Yu}$ D, et al. P53 regulates epithelial-mesenchymal transition and stem cell properties through modulating miRNAs. Nat Cell Biol. 2011; 13:317-323.

35. Wang Z, Zhao Y, Smith E, Goodall GJ, Drew PA, Brabletz T, Yang C. Reversal and prevention of arsenic-induced human bronchial epithelial cell malignant transformation by microRNA-200b. Toxicol Sci. 2011; 121:110-122.

36. Tellez CS, Juri DE, Do K, Bernauer AM, Thomas CL, Damiani LA, Tessema M, Leng S, Belinsky SA. EMT and stem cell-like properties associated with miR-205 and miR200 epigenetic silencing are early manifestations during carcinogen-induced transformation of human lung epithelial cells. Cancer Res. 2011; 71:3087-3097.

37. Chaffer CL, Weinberg RA. A perspective on cancer cell metastasis. Science. 2011; 331:1559-1564.

38. Fidler IJ. The pathogenesis of cancer metastasis: the 'seed and soil' hypothesis revisited. Nat Rev Cancer. 2003; $3: 453-458$

39. Senol O, Schaaij-Visser TBM, Erkan EP, Dorfer C, Lewandrowski G, Pham TV, Piersma SR, Peerdeman SM, Ströbel T, Tannous B, Saydam N, Slavc I, Knosp E, et al. miR-200a-mediated suppression of non-muscle heavy chain IIb inhibits meningioma cell migration and tumor growth in vivo. Oncogene. 2014; doi: 10.1038/onc.2014.120.

40. Sun Y, Shen S, Liu X, Tang H, Wang Z, Yu Z, Li X, Wu M. miR-429 inhibits cells growth and invasion and regulates EMT-related marker genes by targeting Onecut 2 in colorectal carcinoma. Mol Cell Biochem. 2014; 390:19-30.

41. Williams LV, Veliceasa D, Vinokour E, Volpert OV. miR-200b Inhibits Prostate Cancer, EMT, Growth and Metastasis. PLoS ONE. 2013; 8:e83991.

42. Humphries B, Wang Z, Oom AL, Fisher T, Tan D, Cui Y, Jiang Y, Yang C. MicroRNA-200b targets protein kinase $\mathrm{C} \alpha$ and suppresses triple negative breast cancer metastasis. Carcinogenesis. 2014; 35:2254-2263.

43. Li X, Roslan S, Johnstone CN, Wright JA, Bracken CP, Anderson M, Bert AG, Selth LA, Anderson RL, Goodall GJ, Gregory PA, Khew-Goodall Y. MiR-200 can repress breast cancer metastasis through ZEB1-independent but moesindependent pathways. Oncogene. 2014; 33:4077-4088.

44. Iliopoulos D, Lindahl-Allen M, Polytarchou C, Hirsch HA, Tsichlis PN, Struhl K. Loss of miR-200 Inhibition of SUZ12 Leads to Polycomb-Mediated Repression Required for the Formation and Maintenance of Cancer Stem Cells. Mol Cell. 2010; 39:761-772.

45. Folkman J, Kalluri R. Tumor Angiogenesis In: Cancer Medicine 6th Ed. Eds, Holland JF, Frei III E, Bast Jr RC, Kufe DW, Pollock RE, Weichselbaum RR. Hamilton, Ontario: PC Decker Inc. 2002; 1:161-194. Print. 
46. Choi YC, Yoon S, Jeong Y, Yoon J, Baek K. Regulation of vascular endothelial growth factor signaling by miR-200b. Mol Cells. 2011; 32:77-82.

47. McArthur K, Feng B, Wu Y, Chen S, Chakrabarti S. MicroRNA-200b regulates vascular endothelial growth factor-mediated alterations in diabetic retinopathy. Diabetes. 2011; 60:1314-1323.

48. Shi L, Zhang S, Wu H, Zhang L, Dai X, Hu J, Xue J, Liu T, Liang Y, Wu G. MiR-200c increases the radiosensitivity of non-small-cell lung cancer cell line A549 by targeting VEGF-VEGFR2 pathway. PLoS One. 2013; 8:e78344.

49. Roybal JD, Zang Y, Ahn YH, Yang Y, Gibbons DL, Baird BN, Alvarez C, Thilaganathan N, Liu DD, Saintigny P, Heymach JV, Creighton CJ, Kurie JM. miR-200 inhibits lung adenocarcinoma cell invasion and metastasis by targeting Flt1/VEGFR1. Mol Cancer Res. 2011; 9:25-35.

50. Pecot CV, Rupaimoole R, Yang D, Akbani R, Ivan C, Lu C, Wu S, Han HD, Shah MY, Rodriguez-Aguayo C, BottsfordMiller J, Liu Y, Kim SB, et al. Tumour angiogenesis regulation by the miR-200 family. Nat Commun. 2013; 4:2427.

51. Achanzar WE, Brambila EM, Diwan BA, Webber MM, Waalkes MP. Inorganic Arsenite-Induced Malignant Transformation of Human Prostate Epithelial Cells. J Natl Cancer Inst. 2002; 94:1888-1891.

52. Wang Z, Yang J, Fisher T, Xiao H, Jiang Y, Yang C. Akt activation is responsible for enhanced migratory and invasive behavior of arsenic-transformed human bronchial epithelial cells. Environ Health Perspect. 2012; 120:92-97.

53. Zhao CQ, Young MR, Diwan BA, Coogan TP, Waalkes MP. Association of arsenic-induced malignant transformation with DNA hypomethylation and aberrant gene expression. PNAS USA. 1997; 94:10907-10912.

54. Wang Z, Humphries B, Xiao H, Jiang Y, Yang C. Epithelial to mesenchymal transition in arsenic-transformed cells promotes angiogenesis through activating $\beta$-catenin-vascular endothelial growth factor pathway. Toxicol Appl Pharm. 2013; 271:20-29.

55. Sossey-Alaoui K, Bialkowska K, Plow EF. The miR200 Family of MicroRNAs Regulates WAVE3-dependent Cancer Cell Invasion. J Biol Chem. 2009; 284:33019-33029.

56. Jurmeister S, Baumann M, Balwierz A, Keklikoglou I, Ward A, Uhlmann S, Zhang JD, Wiemann S. MicroRNA200c Represses Migration and Invasion of Breast Cancer Cells by Targeting Actin-Regulatory Proteins FHOD1 and PPM1F. Mol Cell Biol. 2012; 32:633-651.

57. Li J, Tan Q, Yan M, Liu L, Lin H, Zhao F, Bao G, Kong H, Ge C, Zhang F, Yu T, Li J, He X, et al. miRNA-200c inhibits invasion and metastasis of human non-small cell lung cancer by directly targeting ubiquitin specific peptidase 25 . Mol Cancer. 2014; 13:166.

58. Aigner K, Dampier B, Descovich L, Mikula M, Sultan A, Schreiber M, Mikulits W, Brabletz T, Strand D, Obrist P, Sommergruber W, Schweifer N, Wernitznig A, et al. The transcription factor ZEB1 promotes tumour cell dedifferentiation by repressing master regulators of epithelial polarity. Oncogene. 2007; 26:6979-6988.

59. Comijn J, Berx G, Vermassen P, Verschueren K, van Grunsven L, Bruyneel E, Mareel M, Huylebroeck D, van Roy F. The two-handed $\mathrm{E}$ box binding zinc finger protein SIP1 downregulates E-cadherin and induces invasion. Mol Cell. 2001; 7:1267-1278.

60. Eger A, Aigner K, Sonderegger S, Dampier B, Oehler S, Schreiber M, Berx G, Cano A, Beug H, Foisner R. DeltaEF1 is a transcriptional repressor of E-cadherin and regulates epithelial plasticity in breast cancer cells. Oncogene. 2005; 24:2375-2385.

61. Gregory PA, Bert AG, Paterson EL, Barry SC, Tsykin A, Farshid G, Vadas MA, Khew-Goodall Y, Goodall GJ. The miR-200 family and miR-205 regulate epithelial to mesenchymal transition by targeting ZEB1 and SIP1. Nat Cell Biol. 2008; 10:593-601.

62. Park SM, Gaur AB, Lengyel E, Peter ME. The miR-200 family determines the epithelial phenotype of cancer cells by targeting the E-cadherin repressors ZEB1 and ZEB2. Genes Dev. 2008; 22:894-907.

63. Gibbons DL, Lin W, Creighton CJ, Rizvi ZH, Gregory PA, Goodall GJ, Thilaganatha N, Du L, Zhang Y, Pertsemlidis A, Kurie JM. Contextual extracellular cues promote tumor cell EMT and metastasis by regulating miR200 family expression. Genes \& Dev. 2009; 23:2140-2151.

64. Bracken CP, Gregory PA, Kolesnikoff N, Bert AG, Wang J, Shannon MF, Goodall GJ. A double-negative feedback loop between ZEB1-SIP1 and the microRNAs-200 family regulates epithelial-mesenchymal transition. Cancer Res. 2008; 68:7846-7854.

65. Burk U, Schubert J, Wellner U, Schmalhofer O, Vincan E, Spaderna S, Brabletz T. A reciprocal repression between ZEB1 and members of the miR-200 family promotes EMT and invasion in cancer cells. EMBO Rep. 2008; 9:582-589.

66. Wang Z, Humphries B, Xiao H, Jiang Y, Yang C. MicroRNA-200b suppresses arsenic-transformed cell migration by targeting protein kinase $\mathrm{C} \alpha$ and Wnt5b protein kinase $\mathrm{C} \alpha$-positive feedback loop and inhibiting Rac1 activation. J Biol Chem. 2014; 289:18373-18386.

67. Bracken CP, Li X, Wright JA, Lawrence DM, Pillman KA, Salmanidis M, Anderson MA, Dredge BK, Gregory PA, Tsykin A, Neilsen C, Thomson DW, Bert AG, Leerberg JM, Yap AS, Jensen KB, Khew-Goodall Y, Goodall GJ. Genome-wide identification of miR-200 targets reveals a regulatory network controlling cell invasion. EMBO J. 2014; 33:2040-2056.

68. Sonoshita M, Aoki M, Fuwa H, Aoki K, Hosogi H, Sakai Y, Hasida H, Takabayashi A, Sasaki M, Robine S, Itoh K, Yoshioka K, Kakizaki F, et al. Suppression of colon cancer metastasis by Aes through inhibition of Notch signaling. Cancer Cell. 2011; 19:125-137.

69. Wyckoff JB, Wang Y, Lin EY, Li JF, Goswami S, Stanley ER, Segall JE, Pollard JW, Condeelis J. Direct 
visualization of macrophage-assisted tumor cell intravasation in mammary tumors. Cancer Res. 2007; 67:2649-2656.

70. Jain RK. Normalization of tumor vasculature: an emerging concept in antiangiogenic therapy. Science. 2005; 307:58-62.

71. Carmeliet P, Jain RK. Principles and mechanisms of vessel normalization for cancer and other angiogenic diseases. Nat Rev Drug Discov. 2011; 10:417-427.

72. Korpal M, Ell BJ, Buffa FM, Ibrahum T, Blanco MA, Celia-Terrassa T, Mercatali L, Khan Z, Goodarzi H, Hua Y, Wei Y, Hu G, Garcia BA, Ragoussis J, Amadori D, Harris AL, Kang Y. Direct targeting of Sec23a by miR-200s influences cancer cell secretome and promotes metastatic colonization. Nat Med. 2011; 17:1101-1108.

73. Uhlmann S, Zhang JD, Schwäger A, Mannsperger H, Riazalhosseini Y, Burmester S, Ward A, Korf U, Wiemann S, miR-200bc/429 cluster targets PLC $\gamma 1$ and differentially regulates proliferation and EGF-driven invasion than miR-200a/141 in breast cancer. Oncogene. 2010; 29:4297-4306.

74. Schickel R, Park SM, Murmann AE, Peter ME. MiR-200c regulates induction of apoptosis through CD95 by targeting FAP-1. Mol Cell. 2010; 38:908-915.

75. Lerner M, Haneklaus M, Harada M, Grandér D. MiR-200c Regulates Noxa Expression and Sensitivity to Proteasomal Inhibitors. PLoS ONE. 2012; 7:e36490.

76. Saydam O, Shen Y, Würdinger T, Senol O, Boke E, James MF, Tannous BA, Stemmer-Rachamimov AO, Yi M, Stephens RM, Fraefel C, Gusella JF, Krichevsky AM, et al. Downregulated MicroRNA-200a in Meningiomas Promotes Tumor Growth by Reducing E-Cadherin and Activating the Wnt/ $\beta$-catenin Signaling Pathway. Mol Cell Biol. 2009; 29:5923-5940.

77. Howe EN, Cochrane DR, Cittelly DM, Richer JK. miR200c Targets a NF- $\kappa \beta$ Up-Regulated TrkB/NTF3 Autocrine Signaling Loop to Enhance Anoikis Sensitivity in Triple Negative Breast Cancer. PLoS ONE. 2012; 7:e49987.

78. Zhang X, Zhang B, Gao J, Wang X, Liu Z. Regulation of the MicroRNA 200b (miRNA-200b) by Transcriptional Regulations PEA3 and ELK-1 Protein Affects Expression of Pin1 Protein to Control Anoikis. J Biol Chem. 2013; 288:32742-32752.

79. Yu SJ, Hu JY, Kuang XY, Luo JM, Hou YF, Di GH, Wu J, Shen ZZ, Song HY, Shao ZM. MicroRNA-200a Promotes Anoikis Resistance and Metastasis by Targeting YAP1 in Human Breast Cancer. Clin Cancer Res. 2013; 19:1389-1399.

80. Drake JM, Strohbehn G, Bair TB, Moreland JG, Henry MD. ZEB1 Enhances Transendothelial Migration and Represses the Epithelial Phenotype of Prostate Cancer Cells. Mol Biol Cell. 2009; 20:2207-2217.

81. Dykxhoorn DM, Wu Y, Xie H, Yu F, Lal A, Petrocca F, Martinvalet D, Song E, Lim B, Lieberman J. miR-200 enhances mouse breast cancer cell colonization to form distant metastases. PLoS One. 2009; 4:e7181.
82. Le MTN, Hamar P, Guo C, Basar E, Perdigão-Henriques R, Balaj L, Lieberman J. miR_200-containing extracellular vesicles promote breast cancer cell metastasis. J Clin Invest. 2014; 124:5109-5128.

83. Mitchell PS, Parkin RK, Kroh EM, Fritz BR, Wyman SK, Pogosova-Agadjanyan EL, Peterson A, Noteboom J, O'Briant KC, Allen A, Lin DW, Urban N, Drescher CW, et al. Circulating microRNAs as stable blood-based markers for cancer detection. PNAS. 2008; 105:10513-10518.

84. Chim SSC, Shing TKF, Hung ECW, Leung TY, Lau TK, Chiu RWK, Lo YMD. Detection and characterization of placental microRNAs in maternal plasma. Clin Chem. 2008; 54:482-490.

85. Lawrie CH, Gal S, Dunlop HM, Pushkaran B, Liggins AP, Pulford K, Banham AH, Pezzella F, Boultwood J, Wainscoat JS, Hatton CSR, Harris AL. Detection of elevated levels of tumour-associated microRNAs in serum of patients with diffuse large B-cell lymphoma. Brit J Haematol. 2008; 141:672-675.

86. Chen X, Ba Y, Ma L, Cai X, Yin Y, Wang K, Guo J, Zhang Y, Chen J, Guo X, Li Q, Li X, Wang W, et al. Characterization of microRNAs in serum: a novel class of biomarkers for diagnosis of cancer and other diseases. Cell Res. 2008; 18:997-1006.

87. Madhavan D, Zucknick M, Wallwiener M, Cuk K, Modugno C, Scharpff M, Schott S, Heil J, Turchinovich A, Yang R, Benner A, Riethdorf S, Trumpp A, et al. Circulating miRNAs as surrogate markers for circulating tumor cells and prognostic markers in metastatic breast cancer. Clin Cancer Res. 2012; 18:5972-5982.

88. Cheng H, Zhang L, Cogdell DE, Zheng H, Schetter AJ, Nykter M, Harris CC, Chen K, Hamilton SR, Zhang W. Circulating plasma miR-141 is a novel biomarker for metastatic colon cancer and predicts poor prognosis. PLoS ONE. 2011; 6:e17745.

89. Park NJ, Zhou H, Elashoff D, Henson BS, Kastratovic DA, Abemayor E, Wong DT. Salivary microRNA: Discovery, characterization, and clinical utility for oral cancer detection. Clin Cancer Res. 2009; 15:5473-5477.

90. Valladares-Ayerbes M, Reboredo M, Medina-Villaamil V, Iglesias-Díaz P, Lorenzo-Patiño MJ, Haz M, Santamarina I, Blanco M, Fernández-Tajes J, Quindós M, Carral A, Figueroa A, Antón-Aparicio LM, et al. Circulating miR$200 \mathrm{c}$ as a diagnostic and prognostic biomarker for gastric cancer. J Transl Med. 2012; 10:186.

91. Xu Y, Brenn T, Brown ERS, Doherty V, Melton DW. Differential expression of microRNAs during melanoma progression: miR-200c, miR-205 and miR-211 are downregulated in melanoma and act as tumour suppressors. Brit J Cancer. 2012; 106:553-561.

92. Brase JC, Johannes M, Schlomm T, Fälth M, Haese A, Steuber T, Beissbarth T, Kuner R, Sültmann HS. Circulating miRNAs are correlated with tumor progression in prostate cancer. Int J Cancer. 2010; 128:608-616. 
93. Barron N, Keenan J, Gammell P, Martinez VG, Freeman A, Masters JR, Clynes M. Biochemical relapse following radical prostatectomy and miR-200a levels in prostate cancer. Prostate. 2012; 72:1193-1199.

94. Hu X, Macdonald DM, Huettner PC, Feng Z, El Naqa IM, Schwarz JK, Mutch DG, Grigsby PW, Powell SN, Wang X. A miR-200 microRNA cluster as prognostic marker in advanced ovarian cancer. Gynecol Oncol. 2009; 114:457-464.

95. Torres A, Torres K, Pesci A, Ceccaroni M, Paszkowski T, Cassandrini P, Zamboni G, Maciejewski R. Diagnostic and prognostic significance of miRNA signatures in tissues and plasma of endometrioid endometrial carcinoma patients. Int J Cancer. 2012; 132:1633-1645.

96. Hummel R, Hussey DJ, Haier J. MicroRNAs: Predictors and modifiers of chemo- and radiotherapy in different tumour types. Eur J Cancer. 2010; 46:298-311.

97. Allen KE, Weiss GJ. Resistance may not be futile: microRNA biomarkers for chemoresistance and potential therapeutics. Mol Cancer Ther. 2010; 9:3126-3136.

98. Lowe SW, Lin AW. Apoptosis in cancer. Carcinogenesis. 2000; 21:485-495.

99. Meng F, Wu G. The rejuvenated scenario of epithelialmesenchymal transition and cancer metastasis. Cancer Metastasis Rev. 2012; 31:455-467.

100. Liu S, Tetzlaff MT, Cui R, Xu X. miR-200c inhibits melanoma progression and drug resistance through downregulation of BMI-1. Am J Pathol. 2012; 181:1823-1835.

101. Glavinas H, Krajcsi P, Cserepes J, Sarkadi B. The role for $\mathrm{ABC}$ transporters in drug resistance, metabolism and toxicity. Curr Drug Deliv. 2004; 1:27-42.

102. Kopp F, Oak PS, Wagner E, Roidl A. miR-200c sensitizes breast cancer cells to doxorubicin treatment by decreasing TrkB and BMI1 expression. PLoS ONE. 2012; 7:e50469.

103. Cochrane DR, Spoelstra NS, Howe EN, Nordeen SK, Richer JK. MicroRNA-200c mitigates invasiveness and restores sensitivity to microtubule-targeting chemotherapeutic agents. Mol Cancer Ther. 2009; 8:1055-1066.

104. Kovalchuk O, Filkowski J, Meservy J, Ilnytskyy Y, Tryndyak VP, Chekhun VF, Pogribny IP. Involvement of microRNA-451 in resistance of the MCF-7 breast cancer cells to chemotherapeutic drug doxorubicin. Mol Cancer Ther. 2008; 7:2152-2159.

105. Pogribny IP, Filkowski JN, Tryndyak VP, Golubov A, Shpyleva SI, Kovalchuk O. Alterations of microRNAs and their targets are associated with acquired resistance of MCF-7 breast cancer cells to cisplatin. Int J Cancer. 2010; 127:1785-1794.

106. Hamano R, Miyata H, Yamasaki M, Kurokawa Y, Hara J, Moon JH, Nakajima K, Takiguchi S, Fujiwara Y, Mori M, Doki Y. Overexpression of miR-200c induces chemoresistance in esophageal cancers mediated through activation of the Akt signaling pathway. Clin Cancer Res. 2011; 17:3029-3038

107. Meng F, Henson R, Lang M, Wehbe H, Maheshwari S, Mendell JT, Jiang J, Schmittgen TD, Patel T. Involvement of human micro-RNA in growth and response to chemotherapy in human cholangiocarcinoma cell lines. Gastroenterology. 2006; 130:2113-2129.

108. Rui W, Bing F, Hai-Zhu S, Wei D, Long-Bang C. Identification of microRNA profiles in docetaxel-resistance human non-small cell lung carcinoma cells (SPCA1). J Cell Mol Med. 2009; 14:206-214.

109. Manavalan TT, Teng Y, Litchfield LM, Muluhngwi P, Al-Rayyan N, Klinge CM. Reduced expression of miR200 family members contributes to antiestrogen resistance in LY2 human breast cancer cells. PLoS ONE. 2013; 8:e62334.

110. Zhu W, Xu H, Zhu D, Zhi H, Wang T, Wang J, Jiang B, Shu Y, Liu P. miR-200bc/429 cluster modulates multidrug resistance of human cancer cell lines by targeting BCL2 and XIAP. Cancer Chemother Pharmacol. 2012; 69:723-731.

111. Shimono Y, Zabala M, Cho RW, Lobo N, Dalerba P, Qian D, Diehn M, Liu H, Panula SP, Chiao E, Dirbas FM, Somlo G, Pera RAR, et al. Downregulation of miR-200c Links Breast Cancer Stem Cells with Normal Stem Cells. Cell. 2009; 138:592-603.

112. Liu S, Tetzlaff MT, Cui R, Xu X. miR-200c inhibits melanoma progression and drug resistance through downregulation of BMI-1. Am J Pathol. 2012; 181:1823-1835.

113. Liu L, Qiu M, Tan G, Liang Z, Qin Y, Chen L, Chen H, Liu J. miR-200c Inhibits invasion, migration and proliferation of bladder cancer cells through down-regulation of BMI-1 and E2F3. J Transl Med. 2014; 12:305.

114. Liu J, Ruan B, You N, Huang Q, Liu W, Dang Z, Xu W, Zhou T, Ji R, Cao Y, Li X, Wang D, Tao K, et al. Downregulation of miR-200a Induces EMT Phenotypes and CSC-like Signatures through Targeting the $\beta$-catenin Pathway in Hepatic Oval Cells. PLoS ONE. 2013; 8:e79409.

115. Xia H, Ng SS, Jaing S, Cheung WK, Bian XW, Kung HF, Lin MC. miR-200a-mediated downregulation of ZEB2 and CTNNB1 differentially inhibits nasopharyngeal carcinoma cell growth, migration and invasion. Biochem Biophys Res Commun. 2010; 391:535-541

116. Yu XY, Zhang Z, Liu J, Zhan B, Kong CZ. MicroRNA-141 is downregulated in human renal cell carcinoma and regulates cell survival by targeting CDC25B. Onco Targets Ther. 2013; 6:349-354.

117. Zhang HF, Zhang K, Liao LD, Li LY, Du ZP, Wu BL, Wu JY, Xu XE, Zeng FM, Chen B, Cao HH, Zhu MX, Dai LH, et al. miR-200b suppresses invasiveness and modulates the cytoskeletal and adhesive machinery in esophageal squamous cell carcinoma cells via targeting Kindlin-2. Carcinogenesis. 2014; 35:292-301. 
118. Korpal M, Lee ES, Hu G, Kang Y. The miR-200 Family Inhibits Epithelial-Mesenchymal Transition and Cancer Cell Migration by Direct Targeting of E-cadherin Transcriptional Repressors ZEB1 and ZEB2. J Biol Chem. 2008; 283:14910-14914.

119. Fu Y, Liu X, Zhou N, Du L, Sun Y, Zhang X, Ge Y. MicroRNA-200b stimulates Tumour Growth in TGFBR2Null Colorectal Cancers by Negatively Regulating p27/ kip1. J Cell Physiol. 2014; 229:772-782.

120. Tang H, Deng M, Tang Y, Xie X, Guo J, Kong Y, Ye F, Su Q, Xie X. miR-200b and miR-200c as Prognostic Factors and Mediators of Gastric Cancer Cell Progression. Clin Cancer Res. 2013; 19:5602-5612.

121. Peng C, Li N, Ng YK, Zhang J, Meier F, Theis FJ, Merkenschlager M, Chen W, Wurst W, Prakash N. A Unilateral Negative Feedback Loop Between miR-200 microRNAs and Sox2/E2F3 Controls Neural Progenitor Cell-Cycle Exit and Differentiation. J Neurosci. 2012; 32:13292-13308.

122. Tao T, Liu D, Liu C, Xu B, Chen S, Yin Y, Ang L, Huang Y, Zhang X, Chen M. Autoregulatory feedback loop of EZH2/miR-200c/E2F3 as a driving force for prostate cancer development. Biochim Biophys Acta. 2014; 1839:858-865.

123. Adam L, Zhong M, Choi W, Qi W, Nicoloso M, Arora A, Calin G, Wang H, Siefker-Radtke A, McConkey D, Bar-Eli M, Dinney C. miR-200 Expression Regulates Epithelial-to-Mesenchymal Transition in Bladder Cancer Cells and Reverses Resistance to Epidermal Growth Factor Receptor Therapy. Clin Cancer Res. 2009; 15:5060-5072.

124. Schliekelman MJ, Gibbons DL, Faca VM, Creighton CJ, Rizvi ZH, Zhang Q, Wong CH, Wang H, Ungewiss C, Ahn YH, Shin DH, Kurie JM, Hanash SM. Targets of the tumor suppressor gene miR-200 in regulation of the epithelial-mesenchymal transition in cancer. Cancer Res. 2011; 71:7670-7682.

125. Gill JG, Langer EM, Lindsley RC, Cai M, Murphy TL, Murphy KM. Snail Promotes the Cell-Autonomous Generation of Flk1+ Endothelial Cells Through the Repression of the microRNA-200 Family. Stem Cells Dev. 2012; 21:167-176.

126. Chan YC, Khanna S, Roy S, Sen CK. miR-200b Targets Ets-1 and Is Down-regulated by Hypoxia to Induce Angiogenic Response of Endothelial Cells. J Biol Chem. 2011; 286:2047-2056

127. Howe EN, Cochrane DR, Richer JK. Targets of miR-200c mediate suppression of cell motility and anoikis resistance. Breast Cancer Res. 2011; 13:R45.

128. Chuang TD, Panda H, Luo X, Chegini N. miR-200c is aberrantly expressed in leiomyomas in an ethnic-dependent manner and targets ZEBs, VEGFA, TIMP2, and FBLN5. Endocr Relat Cancer. 2012; 19:541-556.

129. Chan YC, Roy S, Khanna S, Sen CK. Downregulation of Endothelial MicroRNA-200b Supports Cutaneous Wound
Angiogenesis By Desilencing GATA Binding Protein 2 and Vascular Endothelial Growth Factor Receptor 2. Arterioscl Throm Vas. 2012; 32:1372-1382.

130. Yao CX, Wei QX, Zhang YY, Wang WP, Xue LX, Yang F, Zhang SF, Xiong CJ, Li WY, Wei ZR, Zou Y, Zang MX. miR-200b targets GATA-4 during cell growth and differentiation. RNA Biol. 2013; 10:465-480.

131. Huang HN, Chen SY, Hwang SM, Yu CC, Su MW, Mai W, Wang HW, Cheng WC, Schuyler SC, Ma N, Lu FL, Lu J. miR-200c and GATA binding protein 4 regulate human embryonic stem cell renewal and differentiation. Stem Cell Res. 2014; 12:338-353.

132. Panda H, Pelakh L, Chuang TD, Luo X, Bukulmez O, Chegini N. Endometrial miR-200c is Altered During Transformation into Cancerous States and Targets the Expression of ZEBs, VEGFA, FLT1, IKK $\beta$, KLF9, and FBLN5. Reprod Sci. 2012; 19:786-796.

133. Chuang TD, Khorram O. miR-200c Regulates IL8 Expression by Targeting $I K B K B$. A Potential Inflammation in Leiomyoma Pathogenesis. PLOS One. 2014; 9:e95370.

134. Brabletz S, Bajdak K, Meidhof S, Burk U, Niedermann G, Firat E, Wellner U, Dimmler A, Faller G, Schubert J, Brabletz T. The ZEB1 miR-200 feedback loop controls Notch signaling in cancer cells. EMBO J. 2011; 30:770-782.

135. Eades G, Yang M, Yao Y, Zhang Y, Zhou Q. miR200a regulates Nrf2 activation by targeting KEAP1 mRNA in breast cancer cells. J Biol Chem. 2011; 286:40725-40733.

136. Bimpaki EI, Iliopoulos D, Moraitis A, Stratakis CA. MicroRNA signature in massive macronodular adrenocortical disease and implications for adrenocortical tumorigenesis. Clin Endocrinol. 2010; 72:744-751.

137. Mateescu B, Batista L, Cardon M, Gruosso T, de Feraudy Y, Mariani O, Nicolas A, Meyniel JP, Cottu P, Sastre-Garau X, Mechta-Grigoriou F. miR-141 and miR$200 \mathrm{a}$ act on ovarian tumorigenesis by controlling oxidative stress response. Nat Med. 2011; 17:1627-1635.

138. Luo ML, Gong C, Chen CH, Lee DY, Hu H, Huang P, Yao Y, Guo W, Reinhardt F, Wulf G, Lieberman J, Zhou XZ, Song E, et al. Prolyl Isomerase Pin1 Acts Downstream of miR-200c to Promote Cancer Stemlike Cell Traits in Breast Cancer. Cancer Res. 2014; 74:3603-3616.

139. Cortez MA, Valdecanas D, Zhang X, Zhan Y, Bhardwaj V, Calin GA, Komaki R, Giri DK, Quini CC, Wolfe T, Peltier HJ, Bader AG, Heymach JV, et al. Therapeutic Delivery of miR-200c Enhances Radiosensitivity in Lung Cancer. Mol Ther. 2014; 22:1494-1503.

140. Li R, He JL, Chen XM, Long CL, Yang DH, Ding YB, Qi HB, Liu XQ. MiR-200a is involved in proliferation and apoptosis in the human endometrial adenocarcinoma cell line HEC-1B by targeting the tumor suppressor PTEN. Mol Biol Rep. 2014; 41:1977-1984. 
141. Liao C, Chen W, Fan X, Jiang X, Qiu L, Chen C, Zhu Y, Wang H. MicroRNA-200c inhibits apoptosis in pituitary adenoma cells by targeting the PTEN/Akt signaling pathway. Oncol Res. 2014; 21:129-136.

142. Patel V, Hajarnis S, Williams D, Hunter R, Huynh D, Igarashi P. MicroRNAs Regulate Renal Tubule Maturation through Modulation of Pkd1. JASN. 2012; 23:1941-1948.

143. Zhao WJ, Yang L, He HJ. miR-200b suppresses proliferation of glioma and its stem cells by targeting CD133. Tumor Sci. 2014; 34: DOI:10.3781/j.issn.1000-7431.2014.03.006.

144. Ye F, Tang H, Liu Q, Xie X, Wu M, Liu X, Chen B, Xie X. miR-200b as a prognostic factor in breast cancer targets multiple members of RAB family. J Transl Med. 2014; 12:17.

145. Peng F, Jiang J, Yu Y, Tian R, Guo X, Li X, Shen M, Xu M, Zhu F, Shi C, Hu J, Wang M, Qin R. Direct targeting of SUZ12/ROCK2 by miR-200b/c inhibits cholangiocarcinoma tumourigenesis and metastasis. Brit J Cancer. 2013; 109:3092-3104.

146. Su Y, He Q, Wang J, Liu Q, Wang D, Huang Q, Li G. MiR200a impairs glioma cell growth, migration, and invasion by targeting SIM2-s. Neuroreport. 2014; 25:12-17.

147. Williams KC, Renthal NE, Condon JC, Gerard RD, Mendelson CR. MicroRNA-200a serves a key role in the decline of progesterone receptor function leading to term and preterm labor. PNAS. 2012; 109:7529-7534.
148. Lu YX, Yuan L, Xue XL, Zhou M, Liu Y, Zhang C, Li JP, Zheng L, Hong M, Li XN. Regulation of Colorectal Carcinoma Stemness, Growth, and Metastasis by an $m i R$ 200c-Sox2-Negative Feedback Loop Mechanism. Clin Cancer Res. 2014; 20:1-12.

149. Cui Y, Chen J, He Z, Xiao Y. SUZ12 Depletion Suppresses the Proliferation of Gastric Cancer Cells. Cell Physiol Biochem. 2013; 31:778-784.

150. Cochrane DR, Howe EN, Spoelstra NS, Richer JK. Loss of miR-200c: A Marker of Aggressiveness and Chemoresistance in Female Reproductive Cancers. J Oncol. 2010; 2010: doi:10.1155/2010/821717.

151. Cittelly DM, Dimitrova I, Howe EN, Cochrane DR, Jean A, Spoelstra NS, Post MD, Lu X, Broaddus RR, Spillman MA, Richer JK. Restoration of miR-200c to Ovarian Cancer Reduces Tumor Burden and Increases Sensitivity to Paclitaxel. Mol Cancer Ther. 2012; 11:2556-2565.

152. Prislei S, Martinelli E, Mariani M, Raspaglio G, Sieber S, Ferrandina G, Shahabi S, Scambia G, Ferlini C. MiR-200c and HuR in ovarian cancer. BMC Cancer. 2013; 13:72.

153. Tang H, Kong Y, Guo J, Tang Y, Xie X, Yang L, Su Q, Xie X. Diallyl disulfide suppresses proliferation and induces apoptosis in human gastric cancer through Wnt-1 signaling pathway by up-regulation of miR-200b and miR-22. Cancer Lett. 2013; 340:72-81. 